\title{
Thyroid and Cardiovascular Disease: Research Agenda for Enhancing Knowledge, Prevention, and Treatment
}

\author{
Anne R. Cappola, ${ }_{1}^{1}$ Akshay S. Desai, ${ }^{2}$ Marco Medici, ${ }^{3}$ Lawton S. Cooper, ${ }^{4}$ Debra Egan, ${ }^{5}$ George Sopko, ${ }^{4}$ \\ Glenn I. Fishman, ${ }^{6}$ Steven Goldman, ${ }^{7}$ David S. Cooper, ${ }^{8}$ Samia Mora, ${ }^{9}$ Peter J. Kudenchuk, ${ }^{10}$ \\ Anthony N. Hollenberg, ${ }^{11}$ Cheryl L. McDonald, ${ }^{4}$ and Paul W. Ladenson ${ }^{8}$
}

Thyroid hormones have long been known to have a range of effects on the cardiovascular system. However, significant knowledge gaps exist concerning the precise molecular and biochemical mechanisms governing these effects and the optimal strategies for management of abnormalities in thyroid function in patients with and without preexisting cardiovascular disease. In September 2017, The National Heart, Lung, and Blood Institute convened a Working Group with the goal of developing priorities for future scientific research relating thyroid dysfunction to the progression of cardiovascular disease. The Working Group reviewed and discussed the roles of normal thyroid physiology, the consequences of thyroid dysfunction, and the effects of therapy in three cardiovascular areas: cardiac electrophysiology and arrhythmias, the vasculature and atherosclerosis, and the myocardium and heart failure. This report describes the current state of the field, outlines barriers and challenges to progress, and proposes research opportunities to advance the field, including strategies for leveraging novel approaches using omics and big data. The Working Group recommended research in three broad areas: 1) investigation into the fundamental biology relating thyroid dysfunction to the development of cardiovascular disease and into the identification of novel biomarkers of thyroid hormone action in cardiovascular tissues; 2) studies that define subgroups of patients with thyroid dysfunction amenable to specific preventive strategies and interventional therapies related to cardiovascular disease; and 3) clinical trials focused on improvement in cardiovascular performance and cardiovascular outcomes through treatment with thyroid hormone or thyromimetic drugs.

Keywords: arrhythmia, heart failure, atherosclerosis, lipid, subclinical hypothyroidism, subclinical hyperthyroidism, low T3 syndrome

\section{Introduction}

T HE EFFECTS OF THYROID DYSFUNCTION on the cardiovascular system have been well documented for more than two centuries (1). Clinically, both thyroid hormone excess and deficiency can induce or exacerbate cardiovascular disorders, including atrial and ventricular arrhythmias, atherosclerotic vascular disease, dyslipidemia, and heart failure, thereby contributing to higher risk of premature morbidity and death. Moreover, a growing body of observational data suggests that cardiovascular risk may also be increased in subgroups of patients with subclinical thyrotoxicosis or subclinical

\footnotetext{
${ }^{1}$ Division of Endocrinology, Diabetes, and Metabolism, Perelman School of Medicine at the University of Pennsylvania, Philadelphia, Pennsylvania.

${ }^{2}$ Cardiovascular Division; ${ }^{9}$ Divisions of Preventive and Cardiovascular Medicine; Brigham and Women's Hospital, Boston, Massachusetts.

${ }^{3}$ Department of Internal Medicine and Erasmus MC Academic Center for Thyroid Diseases, Erasmus MC, Rotterdam, The Netherlands.

${ }^{4}$ Division of Cardiovascular Sciences, National Heart, Lung, and Blood Institute, Bethesda, Maryland.

${ }^{5}$ Office of Clinical and Regulatory Affairs, National Center for Complementary and Integrative Health, Bethesda, Maryland.

${ }^{6}$ Division of Cardiology, NYU School of Medicine, New York, New York.

${ }^{7}$ Sarver Heart Center, University of Arizona, Tucson, Arizona.

${ }^{8}$ Division of Endocrinology, Diabetes and Metabolism, Johns Hopkins University School of Medicine, Baltimore, Maryland.

${ }^{10}$ Division of Cardiology, Arrhythmia Services, University of Washington, Seattle, Washington.

${ }^{11}$ Department of Medicine, Weill Cornell Medicine, New York, New York.

This article has been co-published in Circulation.
} 
hypothyroidism. Heightened risk for both incident heart failure and thyroid disease in the aging population threatens a growing burden of both diseases in the coming decades, underscoring the need for greater attention to their intersection.

On the basis of a current literature review and a review of grant funding in these fields, the National Heart, Lung, and Blood Institute (NHLBI) convened a Working Group in Bethesda, MD, on September 8, 2017, to discuss current knowledge and future directions for research in thyroid status and cardiovascular disease (CVD), to stimulate research in this area, and to foster collaboration across disciplines. The Working Group was comprised of a multidisciplinary group of scientists with expertise in basic, clinical, and population sciences pertinent to thyroid and cardiovascular function and dysfunction. It reviewed and discussed the role of normal thyroid physiology, the consequences of thyroid dysfunction, and the effects of therapy in 3 cardiovascular areas: cardiac electrophysiology and arrhythmias, the vasculature and atherosclerosis, and the myocardium and heart failure. In the context of limited available data to address the intersection between thyroid dysfunction and CVD, a particular focus included the opportunities to leverage analysis of extremely large data sets (big data) to provide new insights into diagnosis, risk stratification, and management of thyroid abnormalities. Before the meeting, Working Group members participated in conference calls ( 2 conference calls for each of 4 subgroups) and completed worksheets structured according to the framework of this article: current state of the field, barriers and challenges, and research opportunities. From these worksheets and discussions from the Working Group meeting, National Heart, Lung, and Blood Institute program staff and the Working Group cochairs developed the recommendations outlined here, with additional refinement by the Working Group during article drafting and critical revision. Because recent review articles provide a comprehensive review of the literature on thyroid function and CVD $(2,3)$ and guidelines provide recommendations for clinical care (Table 1), this report briefly summarizes the current state of fundamental, translation, and population science, outlines barriers and challenges to progress, and presents research opportunities to advance the field.

Thyroid status is determined through measurement of thyroid function tests in peripheral blood. Concentrations of thyroid stimulating hormone (TSH), which is produced by the pituitary gland, and the thyroid hormones thyroxine (T4) and triiodothyronine (T3), are easily measured through established assays. Figure 1 provides the classification of thyroid status using these assays. The term "subclinical hyperthyroidism" refers to abnormally low TSH concentrations with free T4 and total or free T3 concentrations within the reference range. However, observational studies frequently determine subclinical hyperthyroidism from only $\mathrm{TSH}$ and free $\mathrm{T} 4$ levels, as T3 levels are usually within the reference range if free $\mathrm{T} 4$ levels are. The form of overt hyperthyroidism called T3 toxicosis, in which free T4 levels are normal and T3 levels are elevated, is uncommon. "Subclinical hypothyroidism" refers to abnormally high TSH concentrations with free T4 levels within the reference range. The low T3 syndrome refers to isolated low T3 levels with free T4 and TSH levels within the reference range (often defined as 0.45-4.5 mIU/L). In addition, throughout this article, the term "hyperthyroidism" denotes thyrotoxicosis caused by both intrinsic ("endogenous") thyroid dysfunction and excessive ("exogenous") thyroid hormone supplementation.

Table 1. Guidelines With Recommendations for Management of Thyroid Dysfunction Coexistent with Cardiovascular Disease

\begin{tabular}{lc}
\hline Condition & Recommendation \\
\hline $\begin{array}{l}\text { Atrial } \\
\text { fibrillation }\end{array}$ & Thyroid testing for a first episode \\
& $(4-7)$ and when ventricular rate \\
& is difficult to control $(5,6)$ \\
& Beta-blocker to control ventricular \\
& rate when complicating \\
& thyrotoxicosis $(5,8,9)$ \\
Heart failure & Thyroid testing at initial presentation
\end{tabular}
(6)

Dilated
cardiomyopathy
Amiodarone use

Subclinical
hyperthyroidism

Overt

hypothyroidism

Subclinical

hypothyroidism
Thyroid testing at initial presentation (10)

Thyroid testing before, within 3 months of initiation, and every 3-6 months (8)

Thyroid testing before, at 1 and 3 months after initiation, and every 3-6 months (9)

If cardiac risk factors or cardiac disease, treat if TSH persistently $<0.1 \mathrm{mIU} / \mathrm{L}(8,9)$

If cardiac disease, consider treatment if TSH persistently $0.1-0.4 \mathrm{mIU} / \mathrm{L}$ $(8,9)$

With known coronary artery disease, start low-dose levothyroxine and increase dose slowly

If unable to tolerate full dose, additional measures to treat CVD are indicated (11)

Treat all patients (12) or consider treatment (13) with TSH level persistently $>10 \mathrm{mIU} / \mathrm{L}$

Consider treatment:

- For patients with TSH levels 4.5-10 mIU/L with ASCVD, heart failure, or associated risk factors for these diseases (13)

- For patients with TSH levels 4.5-10 mIU/L, for those patients younger than 65 years with increased cardiovascular risk (e.g., previous cardiovascular disease, diabetes, dyslipidemia, hypertension, metabolic syndrome), particularly with TSH level persistently $>7 \mathrm{mIU} / \mathrm{L}$ (12)

ASCVD, atherosclerotic cardiovascular disease; CVD, cardiovascular disease; TSH, thyroid-stimulating hormone.

These definitions of thyroid dysfunction are based on the population distribution of serum TSH and free T4 concentrations: levels are deemed abnormal when they are below or above the 2.5th and 97.5th percentiles, respectively. Clinically, a definition that is based on the risk of cardiovascular complications, hypothyroid or hyperthyroid complaints, and the prevention of these complications could direct treatment of thyroid disease. These clinical decision limits, or thresholds, have been used for the definition of many other cardiovascular risk factors, including obesity, dyslipidemia, hypertension, and diabetes mellitus, but they do not exist for thyroid function (14). 


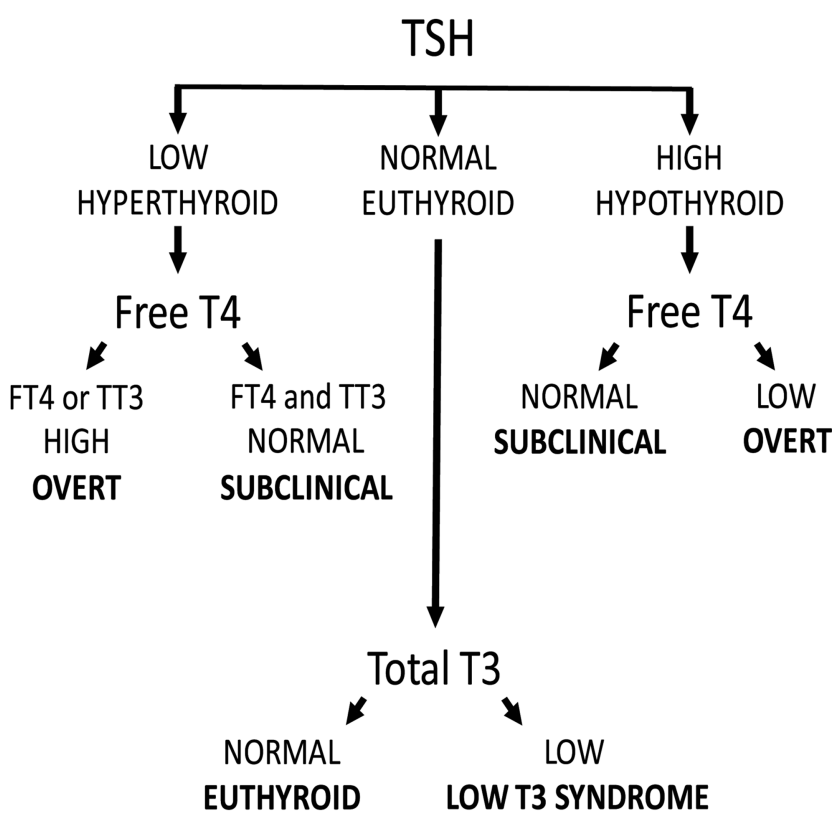

FIG. 1. Commonly defined categories of thyroid status. FT4, free T4; TSH, thyroid-stimulating hormone; TT3, total T3.

\section{OMICS AND BIG DATA}

In this section, we describe the role of large data consortia in refining the application of thyroid function testing to clinical decisions, followed by discussion of barriers and opportunities and research opportunities using omics and big data.

\section{Current state of the field}

The availability of extremely large data sets (big data) that can be analyzed to reveal associations, patterns, and trends in patient- or population-based cohorts provides unique opportunities in medicine. In addition, over the last decade, important progress has been made in epigenomics, transcriptomics, proteomics, and metabolomics (15). These techniques are also likely to play a key role in addressing many of the knowledge gaps in the field of thyroid dysfunction and CVD. Currently, there are two large consortia in the thyroid field: the Thyroid Studies Collaboration (16) and the ThyroidOmics Consortium (17). The Thyroid Studies Collaboration includes $>75,000$ participants from 20 cohorts with thyroid function measurements at baseline and prospective follow-up of cardiovascular outcomes (18-23), and the ThyroidOmics Consortium includes $>80,000$ participants from 34 cohorts with available data on thyroid function and at least one of the aforementioned omics (www.thyroidomics.com) (17,24-26).

The personalized treatment approach, which includes information from the patient's genetic background, would aid in prescribing preventive care for CVD. In healthy individuals, serum thyroid function tests show substantial interindividual variability, leading to wide reference ranges. However, the intraindividual variability lies within a much narrower range. This indicates that every individual has a distinct hypothalamic-pituitary-thyroid (HPT) axis set point within these wide reference ranges (27). On the basis of this construct, patients could therefore still be relatively hypothyroid or hyperthyroid when serum TSH and free T4 levels are normalized to within the reference ranges but deviate from their HPT axis set point. This hypothesis is supported by various studies showing that, despite normalized TSH and free T4 levels, $\sim 15 \%$ of patients treated for hypothyroidism or hyperthyroidism still have significant thyroid-associated complaints (28-32). To what extent a deviation from the HPT axis set point is also important in determining a patient's cardiovascular risk needs to be clarified in future studies. Unfortunately, it is currently not possible to predict an individual's HPT axis set point. However, twin studies have estimated that $\sim 60 \%$ of the variation in serum thyroid parameters is determined by genetic factors (33). In the last decade, genome-wide association studies (GWAS) have successfully identified many new genetic variants that influence TSH and free T4 levels, and the first whole-genome sequencing projects have also identified a few new relevant loci $(34,35)$. However, these known variants together only explain $5-6 \%$ of the variation in serum $\mathrm{TSH}$ and free $\mathrm{T} 4$ levels, which means that many variants could still be awaiting discovery. Therefore, larger genome-wide association studies and whole-genome and -exome sequencing studies are needed to identify the remainder of this missing heritability. The identification of these variants is not only important for HPT axis set-point prediction, but also key to performing reliable Mendelian randomization studies (Fig. 2). Mendelian randomization is a statistical approach using genetic variants to test whether an intermediate phenotype (e.g., thyroid function) is causally related to another phenotype (e.g., coronary heart disease; CHD) (36). This method has the potential to prove direct causality. These studies are particularly needed in the field of thyroid function and cardiovascular complications. Thyroid dysfunction has already been associated with various complications in epidemiological studies, but for many disorders, including CHD and heart failure, direct causality remains unproven. A recent Mendelian randomization study on thyroid function and ischemic heart disease found no effects with genetic determinants of free T4, TSH, or anti-thyroid peroxidase antibodies (37). Despite the large sample size, this study was limited by the small number of genetic variants used. Therefore, Mendelian randomization studies performed in large consortia using more genetic markers are needed to provide clear insights into the true effects of thyroid function on the risk of cardiovascular complications.

All current guidelines recommend TSH levels as the principal guide in the treatment of thyroid diseases because TSH is regarded as the most precise indicator of thyroid function (11). Whereas serum TSH reflects the thyroid status of the pituitary, other peripheral tissues might have a different thyroid status. This is nicely illustrated by patients with thyroid hormone resistance resulting from an inactivating mutation in thyroid hormone receptor (TR) $\beta$ (38). Because $\mathrm{TR} \beta 2$ is the TR in pituitary thyrotrophs, these patients have increased thyroid hormone levels with normal to high TSH levels. Although these TSH levels accurately reflect the thyroid status of TR $\beta$-expressing tissues, they do not accurately reflect the thyroid status of TR $\alpha 1$-expressing tissues in the heart, which may be in a relatively hyperthyroid state, leading to tachycardia (38). Conversely, patients with $\mathrm{TR} \alpha 1$ mutations experience bradycardia and low normal blood pressure (39). When aiming to prevent cardiovascular complications in the treatment of thyroid dysfunction, one would ideally guide treatment by a marker that specifically reflects the thyroid status of the cardiovascular tissues of interest. 


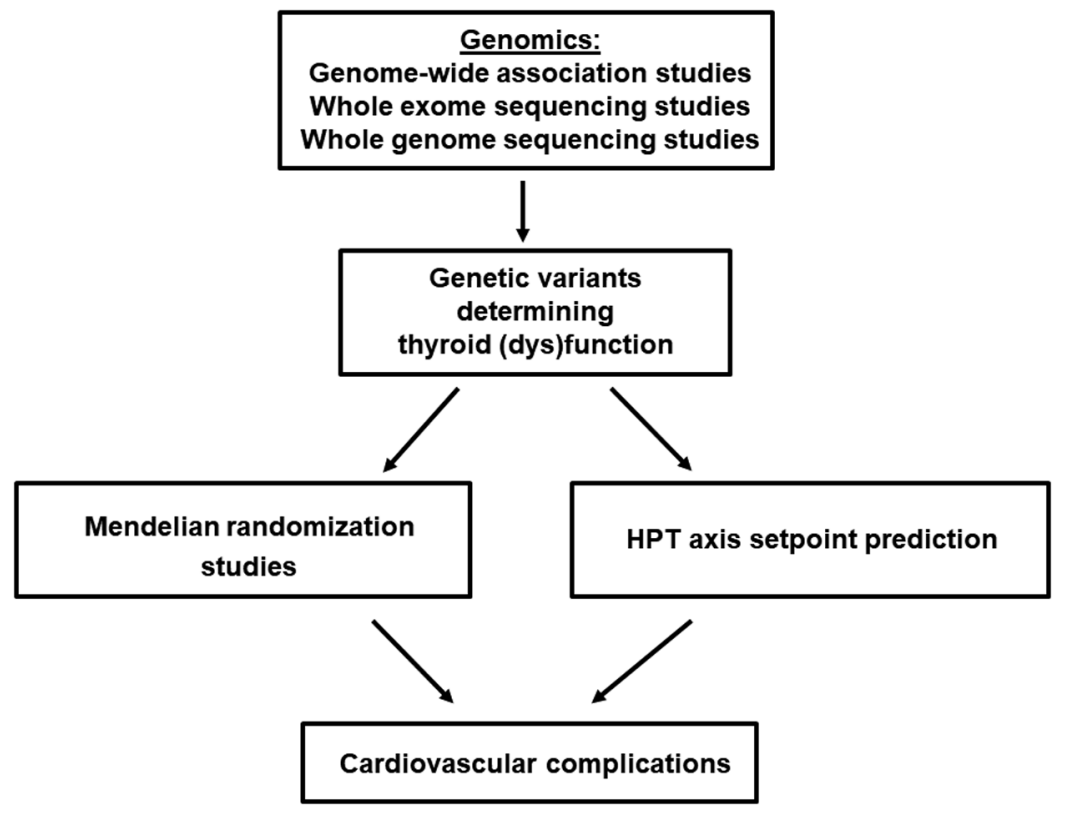

FIG. 2. Role of big data in identifying novel genetic determinants of thyroid (dys)function. The identification of these markers is essential to perform reliable Mendelian randomization studies, which will clarify causality in the observed associations between thyroid (dys)function and cardiovascular complications. Furthermore, these genetic markers could play a role in hypothalamus-pituitary-thyroid (HPT) axis setpoint prediction, which is essential to start personalizing the treatment of patients with thyroid diseases.

\section{Barriers and challenges}

There are too few large population-based cohorts with data on thyroid function, omics, and cardiovascular end points. There has not been harmonization across cohorts of the assays used for thyroid function testing. In addition, a gap in most cohorts is the lack of measurement of T3 levels, and heterogeneity across cohorts in the use of total $\mathrm{T} 3$ and free $\mathrm{T} 3$ assays. In the search for the optimal clinical decision limit, sensitivity analyses in large well-phenotyped cohorts with available data on thyroid function, cardiovascular risk factors, and diseases are required. There may well be differences in decision limits between the various complications, which will require a consensus on the prioritization of the cardiovascular complications.

Besides thyroid dysfunction, other important risk factors such as age, sex, smoking, hypertension, and cholesterol levels determine a patient's cardiovascular risk profile. In further personalization of the management of thyroid diseases, the choice of when to treat should ideally be driven not only by thyroid hormone levels, but also by these other patient-specific characteristics. Finally, better biomarkers of the thyroid state in cardiovascular tissues are needed, as are hypothesis-free approaches to discover new pathways through which thyroid dysfunction leads to CVD.

\section{Research opportunities}

Collaboration among existing cohorts as well as harmonization of measurement variables such as T3 and free T4 will increase the availability of large data sets integrating data on CVDs, omics, and thyroid function. Such consortia can provide the unique framework necessary to perform adequately powered studies that can address many of the knowledge gaps described here. An initial assessment of the various potential cohorts with data available on thyroid function, genetics and omics, cardiovascular diagnoses, and medication use is required for determinations of analytical sample size. The majority of cohorts are lacking one of these essential data sources to participate in these analyses. Many study cohorts have stored blood samples, so it would be most efficient to start with the cohorts lacking thyroid function tests because these tests are relatively inexpensive and easy to determine. Investing in large sample sizes is also important to enable cross-ethnic and sex-specific analyses, as well as gene-environment interaction analyses, including smoking and diet (40). Comparison of the transcriptomics, proteomics, and metabolomics profiles with stratification based on the presence or absence of thyroid dysfunction and cardiovascular complications would be a hypothesis-free approach that could reveal new pathways underlying thyroid dysfunction and CVDs. Similar approaches have previously been proven to effectively identify new pathways involved in atherosclerosis, coronary artery disease, and diabetes mellitus (4143). The combination of the various omics, thyroid function, and CVD data is an excellent starting point in the search for proteins, microRNAs, or metabolites that specifically reflect the thyroid status of particular cardiovascular tissues. Because most of the available cohorts are population-based, findings first need to be confirmed in patient cohorts before they can be translated into clinical practice. Increasingly, registries, insurance databases, and research networks use integrated clinical data systems. Examples include the National Heart, Lung, and Blood Institute Biological Specimen and Data Repositories Information Coordinating Center (BioLINCC), Cardiovascular Research Network (http://cvrn .org), and the Trans-Omics for Precision Medicine (TOPMed) program (https://www.nhlbi.nih.gov/science/trans-omicsprecision-medicine-topmed-program), as well as the All of Us Program (https://allofus.nih.gov). Collaborations with these research networks to perform translational studies could thereby facilitate a faster introduction of new findings into daily clinical practice (www.rethinkingclinicaltrials.org).

\section{CARDIAC ELECTROPHYSIOLOGY AND ARRHYTHMIAS}

In this section, we present a brief summary of laboratorybased and clinical studies of thyroid effects on cardiac electrophysiology and arrhythmias, with a separate discussion of 
amiodarone, followed by a brief discussion of barriers and opportunities and a listing of research opportunities.

\section{Current state of the field}

Laboratory-based studies of cardiac electrophysiology. Thyroid hormones strongly affect cardiac electrophysiology and rhythm through diverse effects on the activity of multiple ion channel subunits, transporters, and exchangers that ultimately regulate cellular excitability (Fig. 3) (44). Accordingly, changes in circulating thyroid hormone levels may alter cardiac excitability and conduction, resulting in heart block and bradyarrhythmias, as well as automatic, triggered, and reentrant supraventricular and ventricular tachyarrhythmias, most commonly atrial fibrillation. These effects depend on whether the thyroid hormone levels are increased or decreased, as explained below. A detailed understanding of the mechanisms through which altered thyroid hormone activity impacts cardiac electrophysiology is of substantial clinical and therapeutic importance.

Genomic effects. Initial molecular studies have identified widespread alterations in the "ion channel transcriptome" in response to altered thyroid hormone status (45). Analyses using cDNA microarrays have detected changes in the abundance of transcripts encoding multiple potassium, sodium, and calcium channel pore-forming and accessory subunits in re- sponse to experimental hyperthyroidism and hypothyroidism, usually associated with commensurate changes in ion channel current density as measured by patch-clamp recordings (45). These include prominent upregulation of the HCN2 pacemaker channel transcript in hyperthyroidism and, conversely, its suppression in hypothyroidism, consistent with changes in heart rate in these conditions (46). Thyroid hormone status also regulates gap junction channel expression and function (47). The hyperthyroid state can be associated with a decrease in ventricular fibrillation threshold (48), potentially a consequence of exaggerated catecholamine tone and/or altered cellcell coupling.

The downstream components of the thyroid hormone signaling axis during heart formation and maturation are incompletely characterized. In situ hybridization studies of the developing murine heart suggest that $\mathrm{TR} \alpha 1$ is enriched in the trabecular myocardium, whereas $\operatorname{TR} \beta 1$ is only weakly expressed (49). These data are consistent with murine knockout studies, in which loss of function of TR $\alpha 1$ produces heart rate slowing and QRS and QT interval prolongation (50). However, the field could greatly benefit from a more precise examination of the individual cellular mechanisms that genomically mediate the thyroid hormone response.

Nongenomic effects. There is also some evidence that thyroid hormones influence cardiac excitability through TR-

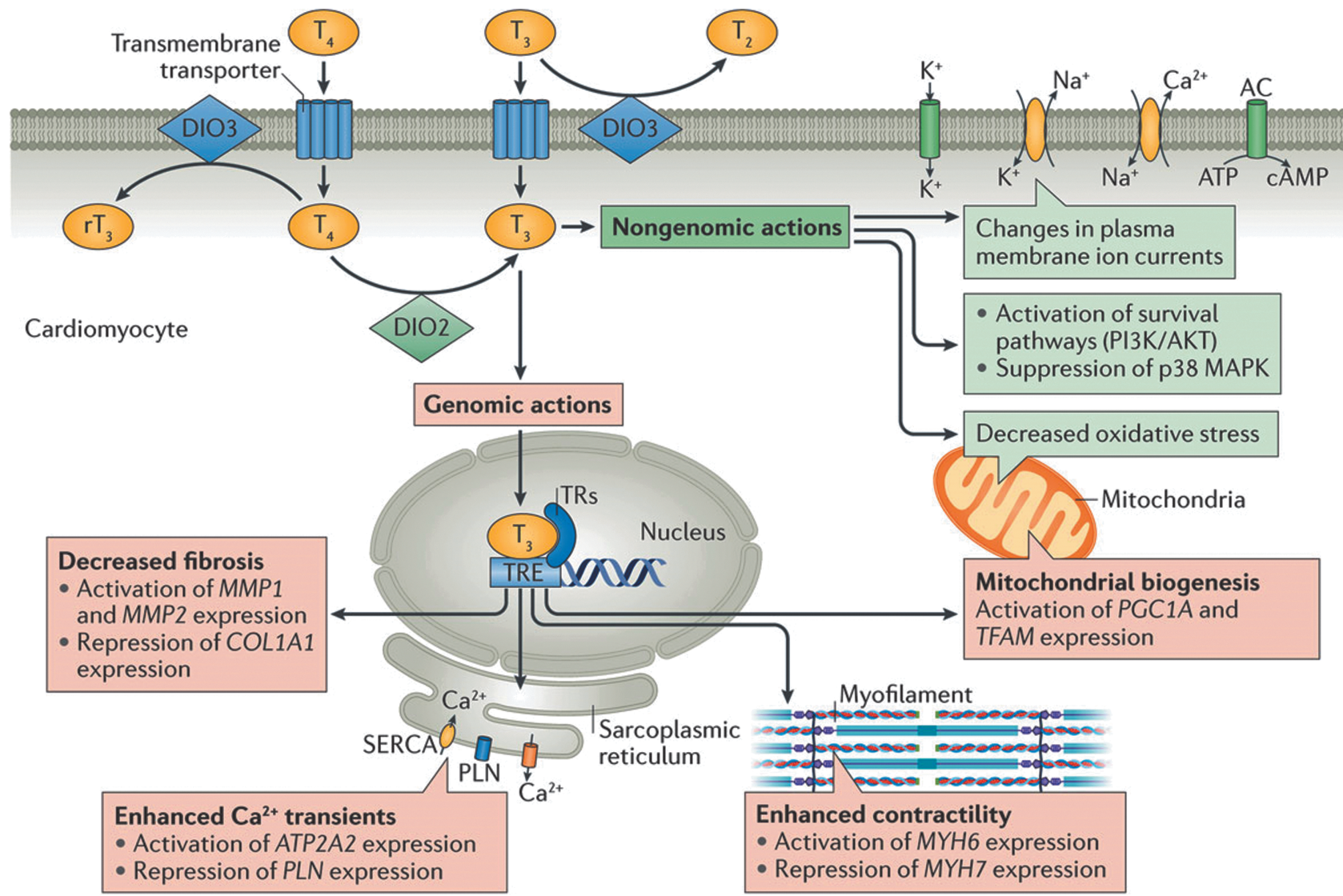

FIG. 3. Effect of thyroid hormones on the cardiomyocyte via genomic and nongenomic actions from Reference (2). Reproduced with permission from Jabbar et al. (2). Copyright (C) 2017, Springer Nature Publishing AG. DIO2, type 2 iodothyronine deiodinase; DIO3, type 3 iodothyronine deiodinase; MAPK, mitogen-activated protein kinase; MYH6, myosin heavy chain $\alpha$; MYH7, myosin heavy chain $\beta$; PI3K, phosphoinositide 3 kinase; PLN, phospholamban; rT3, reverse T3; SERCA, sarco/endoplasmic reticulum $\mathrm{Ca}^{2+}$-ATPase; T2, diiodothyronine; T3, triiodothyronine; T4, thyroxine; TR, thyroid receptor; TRE, thyroid hormone response element. 
independent signaling mechanisms, potentially regulating several electrogenic proteins, including voltage-gated potassium channels, $\mathrm{Na}^{+} / \mathrm{K}^{+}$ATPase, and $\mathrm{Na}^{+} / \mathrm{Ca}^{2+}$ ATPase activities (2). Certainly, evidence for nongenomic actions of thyroid hormone exists in a number of experimental models (51). However, additional information about these so-called nongenomic pathways is needed (52).

Clinical studies of arrhythmias. Clinically, patients with thyroid hormone excess have an increased risk of atrial fibrillation. The threshold of thyroid function at which that risk becomes clinically significant has been the subject of analyses of observational studies. In participants $\geq 60$ years of age and older enrolled in the Framingham Heart Study, TSH $\leq 0.1 \mathrm{mIU} / \mathrm{L}$ was associated with a 3.3 -fold increase in atrial fibrillation risk (53). A subsequent analysis of the Cardiovascular Health Study showed that there was a 2-fold increased risk of atrial fibrillation in individuals $\geq 65$ years of age with a low TSH concentration $(<0.45 \mathrm{mIU} / \mathrm{L})$, even when free T4 concentrations were normal (subclinical hyperthyroidism) (54). There was a 1.85-fold increase in risk, even in those with TSH concentrations of $0.1-0.44 \mathrm{mIU} / \mathrm{L}$. These findings have been confirmed in an individual patient data meta-analysis from the Thyroid Studies Collaboration (22).

Additional analyses have explored whether there is a gradient of risk for developing atrial fibrillation, even within the normal reference range of thyroid function tests. Data show increasing risk with decreasing TSH within the normal reference range in the Rotterdam Study (55) and with increasing free $\mathrm{T} 4$ within the reference range but not with concentrations of TSH or total T3 within their respective reference ranges in the Cardiovascular Health Study (56). This gradient of risk within the reference range was clinically significant in the older population ( $\geq 65$ years of age) enrolled in the Cardiovascular Health Study, with an absolute risk difference of 11 per 1000 person years between the lowest and highest quartiles of free T4 (56). The association between free T4 within the reference range and atrial fibrillation was recently confirmed in a meta-analysis in the Thyroid Studies Collaboration (18).

The relative effects of using different thyroid hormone preparations-levothyroxine, L-triiodothyronine, and combinations of the two hormones (as with desiccated thyroid or synthetic combinations) - on arrhythmia risk have not been well characterized. Both endogenous T4 and levothyroxine have a 7-day half-life, whereas T3 and L-triiodothyronine have a 1-day half-life. T4 is converted to T3 through deiodination. However, levels of T4 and T3 differ between levothyroxine users and individuals in the euthyroid state at similar levels of TSH. Individuals with normal TSH levels who are taking levothyroxine therapy have higher serum free T4 concentrations while taking levothyroxine than when they were in the euthyroid state before a thyroidectomy (57) or compared with individuals in the euthyroid state not taking levothyroxine (58). In addition, levothyroxine users with exogenous subclinical hyperthyroidism have lower T3 levels than their nonuser counterparts with endogenous subclinical hyperthyroidism. These differences suggest that the risks derived from studies of endogenous subclinical hyperthyroidism may not apply to individuals with exogenous subclinical hyperthyroidism. Scottish registry data support an increased risk of arrhythmia in patients taking levothyroxine who have a TSH level $\leq 0.03 \mathrm{mIU} / \mathrm{L}$, but no increase in risk when TSH lies between 0.04 and $0.4 \mathrm{mIU} / \mathrm{L}$ (59), although free T4 and T3 levels were not available in this study. There is concern that exogenous T3 taken in excessive amounts can precipitate arrhythmias, but the threshold at which this risk is increased, and the effects of single versus multiple daily doses, is not known.

Beyond its effects on the genesis of atrial arrhythmias, thyroid hormone can have a paradoxical effect on ventricular repolarization, as reflected in the corrected QT (QTc) interval. Hyperthyroidism has been associated with both QTc prolongation (60) and short QTc intervals (61), and hypothyroidism with QTc prolongation and a heightened risk for torsades de pointes (62). These observations may be attributed to the net effect in context of sympathetic tone, genetic and other medical characteristics of the patient, which determines whether and how a hypothyroid or hyperthyroid state might provoke either bradyarrhythmias or tachyarrhythmias. Thyroid hormonal imbalances, particularly hyperthyroidism, can also exaggerate the effects of catecholamines, enhancing the risk of arrhythmogenesis (63).

Amiodarone. Greater insight into some of the electrophysiological effects of thyroid hormone has been gleaned through understanding the actions of amiodarone. Amiodarone is a highly effective antiarrhythmic agent for both atrial and ventricular arrhythmias with complex electrophysiological effects, including calcium and $\beta$-adrenergic blocking properties, sodium and potassium channel blockade, and a structural similarity to T3. This similarity permits amiodarone to bind to thyroid receptors while being itself incapable of exerting any T3 agonist effects, and once bound, it may act as an antagonist (64). In addition, amiodarone inhibits the $5^{\prime}$ monodeiodinases type I and II enzymes responsible for conversion of $\mathrm{T} 4$ to $\mathrm{T} 3$, thereby blocking peripheral $\mathrm{T} 3$ production and raising circulating free $\mathrm{T} 4$ and lowering $\mathrm{T} 3$ concentrations. Amiodarone also inhibits entry of T4 into cells and the intracellular conversion of $\mathrm{T} 4$ to $\mathrm{T} 3$. Taken together, these actions can result in a functional hypothyroid condition at both systemic and cardiac tissue levels (65). Indeed, many of the therapeutic effects of amiodarone on cardiac automaticity, conduction, and tissue refractoriness mimic a state of physiological thyroid depletion, suggesting that the actions of the drug may be partly or even largely mediated through a thyroid mechanism. These insights afford an opportunity to elucidate arrhythmia mechanisms that might affect pharmacological approaches to arrhythmia management. In addition, amiodarone has been reported to modulate ion channel transcription through mechanisms not fully attributable to drug-induced local hypothyroidism (66). Given the widespread use of amiodarone for atrial fibrillation and other arrhythmias, a more complete understanding of these observations requires further investigation.

Although a highly effective antiarrhythmic agent, the long-term use of amiodarone may be abbreviated by toxicities to the thyroid gland and other organs (65). Depending on the underlying status of the thyroid gland, amiodarone may induce increased thyroid hormone production (type 1 amiodarone-induced thyrotoxicosis) or decreased thyroid hormone production (hypothyroidism) due to effects of the large amounts of iodine it contains ( $37.5 \%$ by weight; $75 \mathrm{mg}$ per $200 \mathrm{mg}$ tablet) on thyroid hormone production. Approximately 
$6 \mathrm{mg}$ of iodine is released by the liver per $200 \mathrm{mg}$ tablet. As a frame of reference, the recommended tolerable upper intake level in the United States is $1.1 \mathrm{mg}$ of iodine per day. Amiodarone can also have a toxic effect on the thyroid gland, causing release of preformed thyroid hormone through thyroiditis (type 2 amiodarone-induced thyrotoxicosis).

\section{Barriers and challenges}

As discussed, significant knowledge gaps remain regarding the effects of thyroid hormone signaling within atrial and ventricular myocytes as well as specialized nodal and His-Purkinje cells. Experimental strategies to perform transcriptional profiling on each of these compartments are now well established (67), and extension of these methods to analyses of non-coding microRNAs and long non-coding RNAs are under development. In addition, the thyroid hormone sensitive gene regulatory networks that are modulated in various systemic disease states have been incompletely characterized.

Although a strong and consistent relationship between higher levels of thyroid hormone and incident atrial fibrillation has been shown, many questions about treatment remain. The target TSH or free T4 for preventing atrial fibrillation treatment and how this might vary by age, race/ethnicity, sex, and underlying cardiac status are not clear. No randomized clinical trials have tested whether treatment of mild hyperthyroidism prevents the new onset of atrial fibrillation or assists in the management of patients with preexisting atrial fibrillation. Nonetheless, several nonrandomized studies have shown a potential benefit of treating subclinical hyperthyroidism. These have shown improvements in heart rate, the frequency of atrial and ventricular premature complexes, left ventricular mass index, systemic vascular resistance, and exercise capacity after normalization of thyroid function (68-70). Parallel knowledge gaps exist for the role of T3 in ventricular arrhythmias. There are as yet no efficient methods for identifying patients with thyroid dysfunction who are at particularly high risk for atrial or ventricular arrhythmias.

Approximately $10 \%$ of people $\geq 65$ years of age take thyroid hormone replacement (71). Data indicate that excess levothyroxine replacement increases the risk of arrhythmias, but the threshold levels of TSH or free T4 at which this risk becomes clinically significant may not parallel those seen in patients with endogenous subclinical hyperthyroidism. Furthermore, there are patients who elect to take thyroid replacement preparations that contain $\mathrm{T} 3$. Because of the shorter half-life of T3, these preparations have more abrupt peak and trough effects. What represents a supraphysiological level of T3 in T3 replacement therapy and the impact that the resulting vacillations in $\mathrm{T} 3$ levels during the day have on the risk for tachyarrhythmias are unstudied.

The mechanism of the direct toxic effects of amiodarone on the thyroid or whether similar pathological processes might account for its other recognized toxicities requires further research. There are no known predictive characteristics to identify a high-risk phenotype for developing thyroid toxicity among patients in the euthyroid state who initiate amiodarone. The optimal frequency of thyroid testing in patients treated with amiodarone and the management of amiodarone-induced thyrotoxicosis and subclinical hypothyroidism also require refinement. Limited data exist on the dosing strategy to guide thyroid hormone replacement in patients taking amiodarone who develop hypothyroidism and on the thyroid function testing targets, along with the type and proper dose of thyroid hormone replacement in any patient with a history of arrhythmias. The two distinct forms of amiodarone-induced thyrotoxicosis have different treatments, and current methods to distinguish between them are imperfect, with some patients demonstrating overlap. Novel circulating markers and/or thyroid imaging techniques are needed for more accurate and prompt differential diagnosis.

\section{Research opportunities}

Specific research priorities defined by the Working Group related to the cardiac electrophysiological effects of thyroid hormone are summarized in Table 2.

\section{VASCULATURE AND ATHEROSCLEROSIS}

In this section, we present a brief summary of thyroid effects on lipid metabolism and other cardiovascular risk factors and a review of clinical studies of thyroid status and cardiovascular events in patients without and with preexisting CVD, followed by a brief discussion of barriers and opportunities and a listing of research opportunities.

\section{Current state of the field}

Thyroid effects on lipid metabolism. There is considerable knowledge about the genomic mechanisms by which thyroid status affects lipid and lipoprotein metabolism. Although T3 induces HMG-CoA reductase, catalyzing the

TABle 2. Research OpPortunities In Thyroid Hormones and Cardiac Electrophysiology

- Studies of thyroid hormone effects on transcriptional and proteomic profiles, and on microRNA and long non-coding RNA expression in atrial, ventricular, nodal, and His-Purkinje myocytes;

- Analyses of thyroid hormone sensitive gene regulatory networks to examine gene expression/phenotype relationships;

- Generation of new experimental animal models to explore the role of altered thyroid hormone signaling as a modulator of arrhythmia risk;

- Mechanisms of amiodarone effects on ion channel transcription;

- Studies in animal models and humans to identify novel biomarkers of the electrophysiological effects of thyroid hormone;

- Identification of the optimal target populations, based on thyroid function test thresholds and absolute risk of arrhythmias, for randomized clinical trials to test the clinical impact of altering thyroid function, particularly of the optimal management of subclinical hyperthyroidism and subclinical hypothyroidism;

- Studies of the effects of levothyroxine and thyroid hormone therapies that include T3 on the conduction system and the role of $\beta$-adrenergic blocking drugs in mitigating risk;

- Use of large databases to examine current practices in the co-existent management of arrhythmias and thyroid disease;

- Management pathways of surveillance for and management of amiodarone-induced thyroid toxicity; common pathways underlying toxicity to the lung. 
initiation of cholesterol biosynthesis, T3 also upregulates hepatic LDL receptor gene expression, mediated by TR-binding elements in the gene promoter region (72). Consequently, LDL cholesterol clearance is slowed in hypothyroidism (73). Thyroid status has also been shown to affect cholesterol $7 \alpha$-hydroxylase activity, the first step in cholesterol degradation, and rates of fecal cholesterol and bile acid excretion $(74,75)$. As a result of these actions, hypothyroidism has been associated with higher levels of LDL cholesterol and apolipoprotein $\mathrm{B}$, as well as unfavorable changes in LDL particle number, size, and oxidation (76).

Thyroid hormone deficiency can increase circulating triglyceride concentrations through lesser activities of lipoprotein lipase, sterol-regulatory-element-binding protein-2, and apolipoprotein A1 (77). Thyroid hormone influences several aspects of HDL metabolism, upregulating hepatic lipase and cholesteryl ester transfer protein (78). In mice, thyroid status has been shown to alter reverse cholesterol transport by increasing levels of the hepatic HDL receptor SR-B1 (79). Finally, a decrease in thyroid hormone has been related to higher levels of atherogenic lipoprotein(a) (80).

In individuals with overt hypothyroidism, abnormal total and LDL cholesterol levels can be partially or completely normalized with thyroid hormone therapy $(76,81)$. The favorable impact of thyroid hormone on the circulating lipid profile is further supported by the lower total and LDL cholesterol levels in endogenous and exogenous thyrotoxicosis (82) and the lowering of total and LDL cholesterol and triglyceride levels observed in clinical trials of TR $\beta$ agonists (83).

Increasing doses of the liver-selective TR $\beta$ agonist eprotirome were associated with LDL cholesterol reduction in a graded manner, with similar effects on apolipoprotein $\mathrm{B}$, triglycerides, and lipoprotein(a) (84). The broad effects of eprotirome on lipids could derive from its specific pharmacodynamics or higher TR $\beta$ engagement in the liver compared with thyroxine.

The effect of subclinical hypothyroidism on lipids and lipoproteins is more controversial. A 2015 U.S. Preventive Services Task Force evidence review found that in eight trials of good or fair quality in which active levothyroxine treatment of subclinical hypothyroidism was compared with passive observation, mean serum total cholesterol reductions ranged from -28 to $0 \mathrm{mg} / \mathrm{dL}$ (85). In only three of these trials was total cholesterol lowering by levothyroxine supplementation statistically significant: $-12,-28$, and $-12 \mathrm{mg} / \mathrm{dL}$, respectively. Similarly, for serum LDL cholesterol, in eight trials of good or fair quality, differences between levothyroxine treatment and observation ranged from -22 to $+2 \mathrm{mg} /$ $\mathrm{dL}$; and in only three trials was LDL cholesterol lowering by levothyroxine significantly greater: $-8,-12$, and $-22 \mathrm{mg} / \mathrm{dL}$, respectively. One recent study found that patients with subclinical hypothyroidism had higher small dense LDL particles - which are more atherogenic than larger less dense particles - only when serum TSH was greater than $10 \mathrm{mIU} / \mathrm{L}$ (86). For serum HDL cholesterol, the U.S. Preventive Services Task Force data review identified no trials finding a significant difference between the levothyroxine-treated and control groups. Finally, for serum triglycerides, in eight good and fair quality trials, differences between levothyroxine treatment and observation ranged from -32 to $+11 \mathrm{mg} / \mathrm{dL}$; and no trial found a significant difference between the levothyroxine-treated and control groups. In the Women's Health Study, higher TSH levels within the normal range and subclinical hypothyroidism were associated, in graded manner, with higher concentrations of small pattern B LDL particles and large VLDL particles (87).

Thyroid status and other cardiovascular risk factors. Approximately one-fourth of overtly hypothyroid patients have reversible, predominantly diastolic, hypertension. Indeed, blood pressure and TSH levels have been correlated, even within the reference range (88). However, the U.S. Preventive Services Task Force evidence review found no blood pressure-lowering effect resulting from levothyroxine treatment in two small trials (85).

Increases in plasma homocysteine levels have been reported in overt hypothyroidism and, in some studies, with subclinical hypothyroidism (89). Overt hypothyroidism has also been firmly associated with other atherosclerotic CVD (ASCVD) risk factors, including altered endothelial function and carotid intima-media thickness and higher uric acid and phosphate levels (90). In some studies, subclinical hypothyroidism has also been associated with other risk factors for ASCVD, including a hypercoagulable state, increased carotid intima-media thickness, decreased flow-mediated vasodilation and nitric oxide availability, and higher high-sensitivity C-reactive proteins levels (3).

Clinical studies of cardiovascular events. No clinical trials have been powered to examine the potential benefits of thyroid hormone supplementation on cardiovascular events in subclinical hypothyroidism; thus, events data are from population-based cohort studies and meta-analyses. An individual patient meta-analysis in the Thyroid Studies Collaboration found that subclinical hypothyroidism was associated with increased risk of CHD events in individuals with a serum TSH concentration $\geq 10 \mathrm{mIU} / \mathrm{L}$ and CHD mortality in individuals with a serum TSH concentration $\geq 7 \mathrm{mIU} / \mathrm{L}$ (16). However, the pathophysiological processes underlying the associations between thyroid dysfunction and CVD are incompletely understood. In studies investigating the relationship between thyroid dysfunction and cardiovascular end points, the associations remain statistically significant after adjustment for cardiovascular risk factors such as lipids and hypertension $(20,22,23)$. This may indicate that thyroid dysfunction affects the risk of cardiovascular complications via other, nontraditional risk factor pathways.

In an observational study of patients in a UK research registry, patients 40 to 70 years of age with subclinical hypothyroidism who were treated with levothyroxine had fewer fatal and nonfatal cardiovascular events compared with nontreated individuals (91). However, no difference in these outcomes was seen between treated and untreated individuals $>70$ years of age.

Additional analyses have explored whether there is a gradient of risk for developing ASCVD, even within the normal reference range of thyroid function tests. In a metaanalysis from the Thyroid Studies Collaboration, there was no association between TSH within the reference range and cardiovascular events, with a trend toward increased risk at higher free T4 levels within the reference range (92). This trend was subsequently confirmed in the Rotterdam Study, with a higher risk of ASCVD events in participants with highnormal free T4 concentrations (93). This is consistent with findings from the Thyroid Studies Collaboration that 
demonstrated an increased risk of CHD events in participants with subclinical hyperthyroidism (22).

Clinical studies of thyroid hormone and preexisting CVD. The effects of correction of thyroid dysfunction in patients with preexisting CVD have not been studied. Low T3 syndrome and subclinical hypothyroidism are commonly observed after acute myocardial infarction and are associated with worse prognosis, though the role of thyroid hormone supplementation in mitigating ischemic-reperfusion injury in humans is not known (3).

\section{Barriers and challenges}

Few reports have examined the effects of thyroid hormone on atherosclerotic cardiovascular disease (ASCVD) in animal models. Limited data are available investigating variation in thyroid hormone action on the vasculature by sex or ethnicity. There are no randomized controlled trials of treatment of thyroid dysfunction with hard cardiovascular outcomes. Arguably, because there are other compelling reasons to treat patients with overt hypothyroidism, prospective studies of cardiovascular outcomes observing untreated individuals or comparing them with thyroid hormone-treated patients would be unethical. However, when to treat subclinical hypothyroidism, based on degree of thyroid dysfunction, age, and underlying cardiac status of the patient, remains unclear. A European trial investigating the impact of levothyroxine treatment in older individuals with persistent subclinical hypothyroidism changed its primary end point from ASCVD events to a symptom-based outcome because of high rates of reversion to euthyroidism and a delay in receiving the study drug (94). Additional studies are needed to identify alternative pathways underlying associations between mild thyroid dysfunction and CVD. There are no data on the effects of T3 therapy on vasculature or ASCVD. There are also no data on the optimal levothyroxine dosing strategy for patients with hypothyroidism who have existing ASCVD or to guide treatment of thyroid dysfunction in individuals after myocardial infarction. There have only been small and short trials studying the impact of thyroid hormone analogs in patients in the euthyroid state. Few observational studies have related the presence of thyroid autoimmunity to CVD, particularly on the basis of age, sex, and ethnicity.

\section{Research opportunities}

Specific research priorities identified by the Working Group for thyroid hormone and atherosclerotic vascular disease are provided in Table 3.

\section{HEART FAILURE AND THE MYOCARDIUM}

In this section, we present a brief summary of the current state of the field, starting with the myocardial and hemodynamic effects of thyroid hormone and studies of thyroid dysfunction in new and established heart failure, followed by a brief discussion of barriers and opportunities and a listing of research opportunities.

\section{Current state of the field}

Myocardial and hemodynamic effects of thyroid hormone. Thyroid hormones play an important physiological role in the regulation of myocardial function (Fig. 4) $(2,95)$.
Table 3. Research Opportunities in Thyroid HORMONES AND THE VASCUlature

- Development of new animal and in vitro models for study of levothyroxine and $\mathrm{T} 3$ effects on the vasculature;

- Studies of thyroid hormone actions on lipid and lipoprotein metabolism, including underlying genetic susceptibility markers, relationships of circulating T4 and T3 to serum lipids, interactions of thyroid hormone action with insulin resistance, efficacy and safety of thyroid hormone analogs, and clinical implications of effects on lipoprotein(a) lowering;

- Analyses of large databases, including collaborative registries, to assess effects of thyroid hormone replacement in patients with preexisting ASCVD;

- Trials of optimal strategies for management of subclinical hyperthyroidism and hypothyroidism in patients with and without ASCVD;

- Roles for thyroid hormones or their analogs in treatment of euthyroid patients with CVD, dyslipidemia, or in the post-MI setting;

- All studies should consider effects based on age, sex, race/ethnicity, and/or presence of autoimmune disease.

Genomic effects. T3 regulates the expression of genes encoding key components of the contractile apparatus, including upregulation of myosin heavy chain- $\alpha(M Y H 6)$ and downregulation of myosin heavy chain- $\beta$ (MYH7), as well as key mediators of intracellular calcium handling, including sarcoplasmic/endoplasmic reticulum calcium ATPase 2 (SERCA2a) and its inhibitor phospholamban $(P L N)(96,97)$. Increased levels of SERCA2a and decreased levels of phospholamban in response to thyroid hormone enhance ventricular relaxation in diastole by enhancing reuptake of calcium into the sarcoplasmic reticulum (98). Thyroid hormones also exert positive inotropic and chronotropic effects by enhancing expression of the $\beta_{1}$-adrenergic receptor (99), although chronotropic effects of thyroid hormone do not require $\beta$-adrenergic signaling (100).

Nongenomic effects. Beyond these direct effects on the myocardium, thyroid hormone reduces systemic vascular resistance by enhancing production of endothelial nitric oxide and increasing calcium reuptake within the arterioles, thereby enhancing vascular smooth-muscle relaxation (101). Vasodilation is further enhanced by increased tissue metabolism and thermogenesis related to effects on mitochondrial function and by elaboration of vasodilatory peptides such as adrenomedullin and the natriuretic peptides, which are also in part regulated by thyroid hormone activity (102-104). The increased cardiac output associated with thyroid hormone does not depend on a low systemic vascular resistance, but is associated with increases in blood volume and systemic venoconstriction that increase the pressure gradient for venous return (105). Secondary activation of the renin-angiotensin-aldosterone axis as a consequence of reduced mean arterial pressure leads to salt and water retention and to plasma volume expansion, which enhances ventricular preload and further augments cardiac output $(106,107)$. 


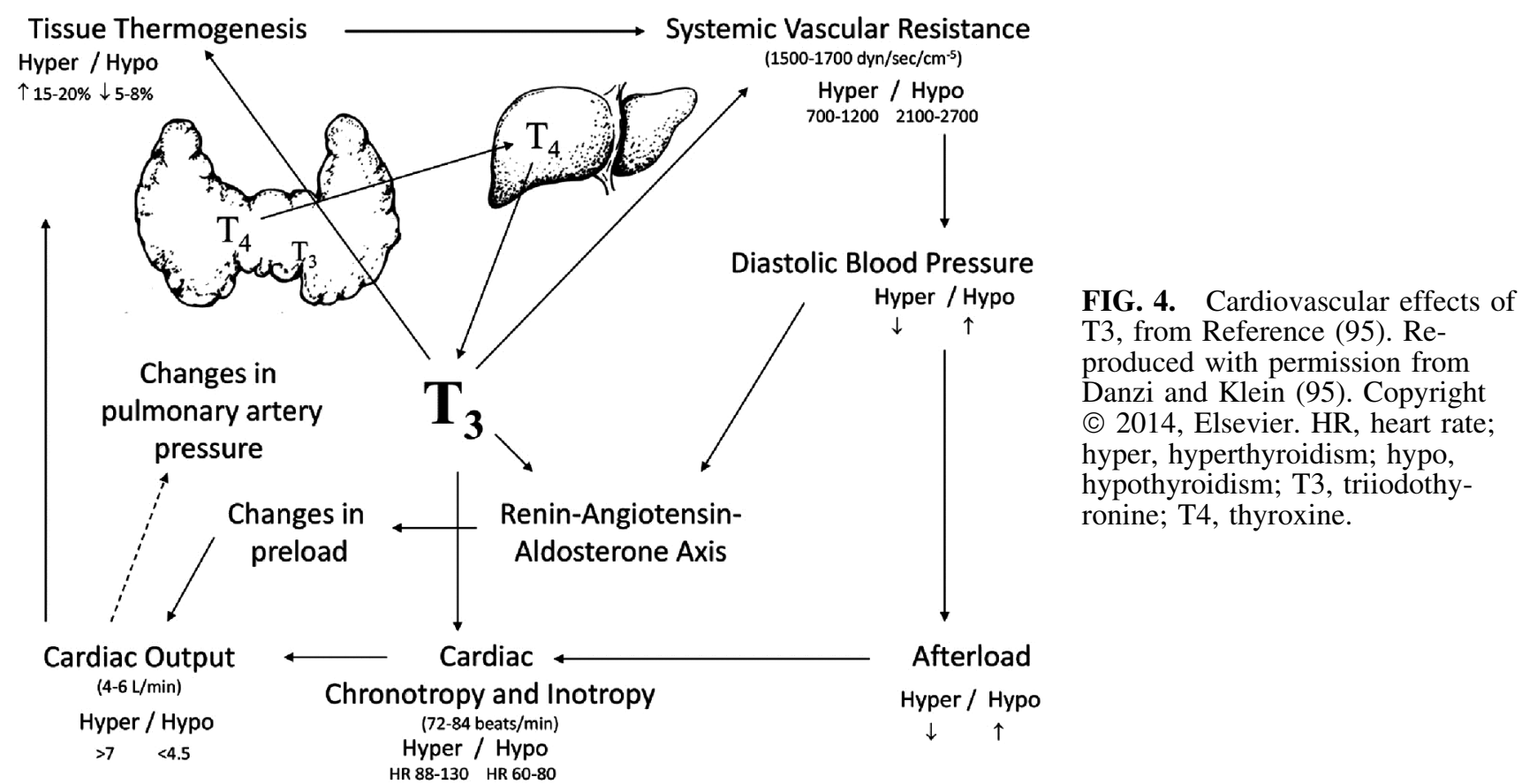

Thyroid dysfunction and the development of heart failure. The hyperdynamic circulation associated with hyperthyroidism, characterized by increased preload, high heart rate, and augmented left ventricular function, results in marked increases in cardiac output that may precipitate heart failure (108). Patients with hyperthyroidism also exhibit elevations in left ventricular mass compared with individuals with euthyroidism, which may represent a substrate for heart failure development (109). Although the precise mechanisms remain undetermined, thyroid hormone is known to participate in the pathogenesis of pulmonary vascular remodeling $(110,111)$, and in population-based cohorts, there is a heightened prevalence of pulmonary hypertension in patients with hyperthyroidism (112). Incident atrial fibrillation in patients with overt hyperthyroidism and subclinical hyperthyroidism may also contribute to development of left ventricular dysfunction as a result of loss of the atrial contribution to enddiastolic volume and tachycardia-related effects on cardiac performance.

Patients with hypothyroidism exhibit impaired ventricular relaxation related to reductions in SERCA2a gene expression, increased expression of phospholamban, and associated reductions in intracellular calcium reuptake, as well as reductions in left ventricular stroke volume and cardiac index both at rest and during exercise (2). Untreated hypothyroidism can cause biventricular heart failure when profound and prolonged, but many of these physiological abnormalities can be reversed with thyroid hormone supplementation and restoration of a euthyroid status. These hemodynamic abnormalities likely contribute to the heightened risk of incident heart failure associated with subclinical hypothyroidism in individuals with serum $\mathrm{TSH} \geq 10 \mathrm{mIU} / \mathrm{L}$, as shown in an individual patient meta-analysis of the Thyroid Studies Collaboration (23).

Thyroid hormone in established heart failure. In patients with established heart failure, low T3 levels are common (as a result of impaired T4-to-T3 conversion), and the decline in serum T3 is proportional to the severity of left ventricular dysfunction (113). Reduced T3 in the presence of normal TSH and free T4 concentrations - the low T3 syndrome-is a powerful predictor of all-cause mortality in heart failure (114), even after adjustment for conventional predictors, including ejection fraction and natriuretic peptide levels (115). At the tissue level, diminished T3 bioavailability may be related to tissue hypoxia and inflammation, which conspire to reduce deiodinase activity in the cardiomyocyte, and also to an increase in DIO3 gene expression, which accelerates the degradation of T3 into inactive metabolites (116). Although in one small trial T3 replacement was associated with improvements in systolic and diastolic function and a reduction in neurohormonal activation (117), another study failed to confirm these benefits in patients with less severe heart failure (118). T3 is routinely administered to heart transplant donors and recipients to improve function, but no randomized studies support this practice (119). A prospective randomized trial of supplemental T3 in patients after coronary artery bypass grafting was negative (120). A multicenter clinical trial with a thyroid hormone analog, 3,5-diodothyroproprionic acid (DITPA), did not improve clinical outcomes in patients with heart failure but did increase cardiac index, decrease left ventricular size, and lower LDL cholesterol and body weight (121). In the Third National Health and Nutrition Examination Survey, in patients with preexisting heart failure, subclinical hypothyroidism was associated with increased mortality rates compared with control subjects with euthyroidism, especially in blacks (122). Clinical trials have not focused exclusively on this population.

Experimental data suggest that patients with heart failure may exhibit diminished responsiveness to thyroid hormone because of abnormalities in TR expression (123). Limited data in mouse hearts with ascending aortic constriction-induced cardiac hypertrophy and decreased cardiac contractile function 
show a marked decrease of TR $\alpha 1$ and $\mathrm{TR} \beta$ mRNA levels (124). Restoration of TR levels by adeno-associated virus (AAV) transgene expression significantly improves cardiac contractile function (124). In humans, a decrease in $\mathrm{TR} \alpha 1$ has been reported in patients with cardiomyopathies (125).

\section{Barriers and challenges}

Thyroid hormones play a number of key roles in the regulation of cardiovascular performance. However, the possible contributions of thyroid dysregulation to the pathogenesis of heart failure remain insufficiently studied. Specifically, although overt hypothyroidism and hyperthyroidism are clear targets for therapy in patients with established heart failure, it remains unclear whether subclinical thyroid dysfunction requires similar attention. Similarly, the contributions of altered myocardial thyroid hormone actions in patients with euthyroidism with heart failure are still obscure. Although T3 bioavailability is thought to play a key role in modulating myocardial function, there is a lack of data regarding which specific myocardial effects of T3 play a significant role in development of human heart failure and might represent targets for therapy with T4, T3, or thyroid hormone analogs. Epidemiological data investigating subclinical thyroid dysfunction and preexisting heart failure are lacking, and the

TABle 4. Research OpPortunities in Thyroid HORMONES AND THE MYOCARDIUM

- Studies of thyroid hormone effects on transcriptional and proteomic profiles, and on microRNAs, in the normal myocardium and on cardiac remodeling;

- Studies of the effects of full length and truncated TR proteins in animal models of heart failure;

- Studies in animal models and humans relating thyroid hormone receptor levels to cardiac structure and function;

- Human data relating tissue T3 levels to myocardial structure, myocardial function, and clinical outcomes in heart failure, and investigation into the mechanistic underpinnings of the low T3 syndrome in patients with heart failure;

- Epidemiologic investigations to explore the association between subclinical thyroid dysfunction and incident heart failure, as well as the impact of subclinical thyroid dysfunction on disease progression in patients with established heart failure across the spectrum of ejection fraction. These studies could be undertaken in banked sera from established epidemiologic cohorts with long duration follow-up of cardiovascular outcomes or from completed therapeutic trials of patients with established heart failure. Sampling of diverse cohorts may inform variations in these associations according to age, sex, race, and ethnicity;

- Prospective clinical trials to define the appropriate thresholds for triggering therapy of thyroid dysfunction in patients at risk for heart failure and those with established disease;

- Adequately powered randomized clinical trials to test the effects of thyroid hormone supplementation in patients with heart failure phenotypes and low T3, and in patients with heart failure phenotypes and subclinical thyroid dysfunction. mechanism by which subclinical hypothyroidism and the low T3 syndrome enhance the risk of mortality in established heart failure patients remains to be studied.

Accurate quantification of tissue-level thyroid hormone action also remains a challenge. Although serum T3 levels can be measured easily, no methods are currently available for accurate quantification of tissue T3 levels, which may be more tightly correlated to myocardial function. Indeed, it is also not clear how thyroid hormone transporters, which are essential for T3 transport into cells, are regulated in the heart. There are also limited data on TR levels in animal models with heart failure and in patients with heart failure, and no data on contractile and electrophysiological effects of truncated $\operatorname{TR} \alpha$ and $\operatorname{TR} \beta$ proteins in cardiac myocytes.

The effects of thyroid hormone supplementation on heart failure prevention among those at risk and on cardiovascular outcomes in patients with established CVD also require further investigation. There are no prospective, randomized trials of thyroid hormone supplementation in patients with chronic heart failure with reduced ejection fraction or preserved ejection fraction and low serum T3 levels, and there is limited understanding of the optimal thresholds for therapy of thyroid hormone abnormalities in patients with established heart failure. Further data are needed on the role of thyroid abnormalities in key heart failure subsets such as those with heart failure and preserved ejection fraction or those with acute decompensated heart failure or cardiogenic shock.

\section{Research opportunities}

Specific research priorities on thyroid hormone effects on heart failure pathogenesis are summarized in Table 4.

\section{Conclusions and Recommendations}

Based on discussion at the meeting, the Working Group defined three broad recommendations for research activity. The first set of recommendations focuses on basic biology. The second and third recommendations, with their focus on refining thresholds and testing treatment strategies in clinical trials, have more immediate translational potential.

1. Investigation into the fundamental biology relating thyroid dysfunction to the development of CVD and into the identification of novel biomarkers of thyroid hormone action in cardiovascular tissues.

Areas of particular interest for further research include the following:

- Defining the cellular signaling processes and gene expression variations by which thyroid hormone regulates electric conduction, contractility, and peripheral vascular function;

- Defining the cellular and molecular mechanisms relating thyroid hormone action to incident atrial and ventricular arrhythmias;

- Examining the role of thyroid hormone, its receptors, and cofactors in modulating myocardial systolic and diastolic function;

- Exploring the role of thyroid hormone in the setting of ischemia and its responsiveness to thyroid modulating agents;

- Exploring the role of thyroid hormone in modulation of endothelial function; 
- Examining the mechanisms by which cardiac medications affect thyroid hormone production or action; and

- Developing novel serum and imaging biomarkers reflecting tissue thyroid hormone actions.

2. Studies that define subgroups of patients with thyroid dysfunction amenable to specific preventive strategies and interventional therapies related to cardiovascular disease.

Areas of particular interest include the following:

- Identifying subgroups of individuals with preexisting CVD or at high risk for CVD who may benefit from manipulation of thyroid hormone status, including individuals in the euthyroid state. These studies would potentially support thresholds for treatment (based on specific levels of thyroid function tests) that vary by subgroup characteristics;

- Using modern approaches including genome-wide association studies, whole-exome/genome sequencing, epigenetics, mRNA expression, metabolomics, and other omics data to generate an HPT (hypothalamicpituitary-thyroid) axis set-point prediction model to personalize treatment of thyroid dysfunction and test to what extent a deviation from the HPT axis set point is also important in determining a patient's cardiovascular risk;

- Recognizing the developmental and mechanistic differences among the newborn, pediatric, and adult populations; potential variations in key demographic subgroups, including age, sex, and race/ethnicity; and issues of health disparities and global health; and

- Leveraging the infrastructure from the two existing large consortia in this field (Thyroid Studies Collaboration and ThyroidOmics Consortium) to integrate data from existing large-scale cohorts or use existing registries.

3. Clinical trials focused on improvement in cardiovascular performance and cardiovascular outcomes through treatment with thyroid hormone or drugs exploiting known thyroid hormone actions.

Areas of particular interest for further research include the following:

- Designing studies, including small clinical trials designed to evaluate the feasibility and rationale for large intervention studies and test optimal strategies for management of subclinical hyperthyroidism, subclinical hypothyroidism, and low T3 syndrome in patients with and without preexisting CVD; these studies might test the treatment thresholds suggested by subgroup analyses of observational data;

- Designing studies, including small clinical trials, designed to justify large intervention studies of targeted thyromimetic analogs to treat dyslipidemia, heart failure, and peripheral vascular dysfunction;

- Incorporating appropriate examination of the HPT axis for new cardiovascular therapies for which preclinical data suggest an effect on the thyroid;

- Identifying appropriate surrogate (intermediate) end points for small clinical trials to help plan large intervention studies; and
- Establishing consortia to identify priority areas for therapeutic pharmacology studies and provide centralized protocol coordination, data management, and end point assessment for multicenter studies.

\section{Disclaimer}

The views expressed in this article are those of the authors and do not necessarily represent the views of the NHLBI; the National Institutes of Health; the U.S. Departments of Veterans Affairs, and Health and Human Services; or the U.S. government.

\section{Author Disclosure Statement}

Dr. Desai reports a research grant from Novartis and consulting fees from Novartis, Abbott, AstraZeneca, Boston Scientific, Bohringer-Ingelheim, Corvidia Therapeutics, Dalcor Pharma, Regeneron, Relypsa, and Signature Medical. Dr. Mora reports a research grant from Atherotech Diagnostics.

\section{References}

1. Parry CH 1815 Elements of Pathology and Therapeutics: Being the Outlines of a Work. R. Cruttwell, Bath, United Kingdom.

2. Jabbar A, Pingitore A, Pearce SH, Zaman A, Iervasi G, Razvi S 2017 Thyroid hormones and cardiovascular disease. Nat Rev Cardiol 14:39-55.

3. Razvi S, Jabbar A, Pingitore A, Danzi S, Biondi B, Klein I, Peeters R, Zaman A, Iervasi G 2018 Thyroid hormones and cardiovascular function and diseases. J Am Coll Cardiol 71:1781-1796.

4. Page RL, Joglar JA, Caldwell MA, Calkins H, Conti JB, Deal BJ, Estes NA 3rd, Field ME, Goldberger ZD, Hammill SC, Indik JH, Lindsay BD, Olshansky B, Russo AM, Shen WK, Tracy CM, Al-Khatib SM; Evidence Review Committee Chair 20162015 ACC/AHA/HRS guideline for the management of adult patients with supraventricular tachycardia: a report of the American College of Cardiology/American Heart Association Task Force on clinical practice guidelines and the Heart Rhythm Society. Circulation 133: e506-574.

5. January CT, Wann LS, Alpert JS, Calkins H, Cigarroa JE, Cleveland JC Jr, Conti JB, Ellinor PT, Ezekowitz MD, Field ME, Murray KT, Sacco RL, Stevenson WG, Tchou PJ, Tracy CM, Yancy CW; ACC/AHA Task Force Member 20142014 AHA/ACC/HRS guideline for the management of patients with atrial fibrillation: a report of the American College of Cardiology/American Heart Association Task Force on practice guidelines and the Heart Rhythm Society. Circulation 130:e199-267.

6. Writing Committee M, Yancy CW, Jessup M, Bozkurt B, Butler J, Casey DE Jr, Drazner MH, Fonarow GC, Geraci SA, Horwich T, Januzzi JL, Johnson MR, Kasper EK, Levy WC, Masoudi FA, McBride PE, McMurray JJ, Mitchell JE, Peterson PN, Riegel B, Sam F, Stevenson LW, Tang WH, Tsai EJ, Wilkoff BL; American College of Cardiology Foundation/American Heart Association Task Force on Practice Guidelines 20132013 ACCF/ AHA guideline for the management of heart failure: a report of the American College of Cardiology Foundation/ 
American Heart Association Task Force on practice guidelines. Circulation 128: 240-327.

7. Al-Khatib SM, Arshad A, Balk EM, Das SR, Hsu JC, Joglar JA, Page RL 2016 Risk stratification for arrhythmic events in patients with asymptomatic pre-excitation: a systematic review for the 2015 ACC/AHA/HRS guideline for the management of adult patients with supraventricular tachycardia: a report of the American College of Cardiology/American Heart Association Task Force on clinical practice guidelines and the Heart Rhythm Society. J Am Coll Cardiol 67:1624-1638.

8. Ross DS, Burch HB, Cooper DS, Greenlee MC, Laurberg P, Maia AL, Rivkees SA, Samuels M, Sosa JA, Stan MN, Walter MA 20162016 American Thyroid Association guidelines for diagnosis and management of hyperthyroidism and other causes of thyrotoxicosis. Thyroid 26: 1343-1421.

9. Bahn Chair RS, Burch HB, Cooper DS, Garber JR, Greenlee MC, Klein I, Laurberg P, McDougall IR, Montori VM, Rivkees SA, Ross DS, Sosa JA, Stan MN; American Thyroid Association; American Association of Clinical Endocrinologists 2011 Hyperthyroidism and other causes of thyrotoxicosis: management guidelines of the American Thyroid Association and American Association of Clinical Endocrinologists. Thyroid 21:593-646.

10. Bozkurt B, Colvin M, Cook J, Cooper LT, Deswal A, Fonarow GC, Francis GS, Lenihan D, Lewis EF, McNamara DM, Pahl E, Vasan RS, Ramasubbu K, Rasmusson K, Towbin JA, Yancy C; American Heart Association Committee on Heart Failure and Transplantation of the Council on Clinical Cardiology; Council on Cardiovascular Disease in the Young; Council on Cardiovascular and Stroke Nursing; Council on Epidemiology and Prevention; and Council on Quality of Care and Outcomes Research 2016 Current diagnostic and treatment strategies for specific dilated cardiomyopathies: a scientific statement from the American Heart Association. Circulation 134:e579-e646.

11. Jonklaas J, Bianco AC, Bauer AJ, Burman KD, Cappola AR, Celi FS, Cooper DS, Kim BW, Peeters RP, Rosenthal MS, Sawka AM; American Thyroid Association Task Force on Thyroid Hormone Replacement 2014 Guidelines for the treatment of hypothyroidism: prepared by the American Thyroid Association Task Force on Thyroid Hormone Replacement. Thyroid 24:1670-1751.

12. Brenta G, Vaisman M, Sgarbi JA, Bergoglio LM, Andrada NC, Bravo PP, Orlandi AM, Graf H; Task Force on Hypothyroidism of the Latin American Thyroid Society (LATS) 2013 Clinical practice guidelines for the management of hypothyroidism. Arq Bras Endocrinol Metabol 57:265-291.

13. Garber JR, Cobin RH, Gharib H, Hennessey JV, Klein I, Mechanick JI, Pessah-Pollack R, Singer PA, Woeber KA; American Association of Clinical Endocrinologists and American Thyroid Association Taskforce on Hypothyroidism in Adults 2012 Clinical practice guidelines for hypothyroidism in adults: cosponsored by the American Association of Clinical Endocrinologists and the American Thyroid Association. Thyroid 22:1200-1235.

14. Bennett CM, Guo M, Dharmage SC $2007 \mathrm{HbA}(1 \mathrm{c})$ as a screening tool for detection of type 2 diabetes: a systematic review. Diabet Med 24:333-343.

15. Hasin Y, Seldin M, Lusis A 2017 Multi-omics approaches to disease. Genome Biol 18:83.
16. Rodondi N, den Elzen WP, Bauer DC, Cappola AR, Razvi S, Walsh JP, Asvold BO, Iervasi G, Imaizumi M, Collet TH, Bremner A, Maisonneuve P, Sgarbi JA, Khaw KT, Vanderpump MP, Newman AB, Cornuz J, Franklyn JA, Westendorp RG, Vittinghoff E, Gussekloo J; Thyroid Studies Collaboration 2010 Subclinical hypothyroidism and the risk of coronary heart disease and mortality. JAMA 304:1365-1374.

17. Medici M, Porcu E, Pistis G, Teumer A, Brown SJ, Jensen RA, Rawal R, Roef GL, Plantinga TS, Vermeulen SH, Lahti J, Simmonds MJ, Husemoen LL, Freathy RM, Shields BM, Pietzner D, Nagy R, Broer L, Chaker L, Korevaar TI, Plia MG, Sala C, Volker U, Richards JB, Sweep FC, Gieger C, Corre T, Kajantie E, Thuesen B, Taes YE, Visser WE, Hattersley AT, Kratzsch J, Hamilton A, Li W, Homuth G, Lobina M, Mariotti S, Soranzo N, Cocca M, Nauck M, Spielhagen C, Ross A, Arnold A, van de Bunt M, Liyanarachchi S, Heier M, Grabe HJ, Masciullo C, Galesloot TE, Lim EM, Reischl E, Leedman PJ, Lai S, Delitala A, Bremner AP, Philips DI, Beilby JP, Mulas A, Vocale M, Abecasis G, Forsen T, James A, Widen E, Hui J, Prokisch H, Rietzschel EE, Palotie A, Feddema P, Fletcher SJ, Schramm K, Rotter JI, Kluttig A, Radke D, Traglia M, Surdulescu GL, He H, Franklyn JA, Tiller D, Vaidya B, de Meyer T, Jorgensen T, Eriksson JG, O'Leary PC, Wichmann E, Hermus AR, Psaty BM, Ittermann T, Hofman A, Bosi E, Schlessinger D, Wallaschofski H, Pirastu N, Aulchenko YS, de la Chapelle A, Netea-Maier RT, Gough SC, Meyer Zu Schwabedissen H, Frayling TM, Kaufman JM, Linneberg A, Raikkonen K, Smit JW, Kiemeney LA, Rivadeneira F, Uitterlinden AG, Walsh JP, Meisinger C, den Heijer M, Visser TJ, Spector TD, Wilson SG, Volzke H, Cappola A, Toniolo D, Sanna S, Naitza S, Peeters RP 2014 Identification of novel genetic Loci associated with thyroid peroxidase antibodies and clinical thyroid disease. PLoS Genet 10:e1004123.

18. Baumgartner C, da Costa BR, Collet TH, Feller M, Floriani C, Bauer DC, Cappola AR, Heckbert SR, Ceresini G, Gussekloo J, den Elzen WPJ, Peeters RP, Luben R, Volzke H, Dorr M, Walsh JP, Bremner A, Iacoviello M, Macfarlane P, Heeringa J, Stott DJ, Westendorp RGJ, Khaw KT, Magnani JW, Aujesky D, Rodondi N; Thyroid Studies Collaboration 2017 Thyroid function within the normal range, subclinical hypothyroidism, and the risk of atrial fibrillation. Circulation 136:2100-2116.

19. Chaker L, Baumgartner C, den Elzen WP, Collet TH, Ikram MA, Blum MR, Dehghan A, Drechsler C, Luben RN, Portegies ML, Iervasi G, Medici M, Stott DJ, Dullaart RP, Ford I, Bremner A, Newman AB, Wanner C, Sgarbi JA, Dorr M, Longstreth WT Jr, Psaty BM, Ferrucci L, Maciel RM, Westendorp RG, Jukema JW, Ceresini G, Imaizumi M, Hofman A, Bakker SJ, Franklyn JA, Khaw KT, Bauer DC, Walsh JP, Razvi S, Gussekloo J, Volzke $\mathrm{H}$, Franco OH, Cappola AR, Rodondi N, Peeters RP; Thyroid Studies Collaboration 2016 Thyroid function within the reference range and the risk of stroke: an individual participant data analysis. J Clin Endocrinol Metab 101:4270-4282.

20. Chaker L, Baumgartner C, den Elzen WP, Ikram MA, Blum MR, Collet TH, Bakker SJ, Dehghan A, Drechsler C, Luben RN, Hofman A, Portegies ML, Medici M, Iervasi G, Stott DJ, Ford I, Bremner A, Wanner C, Ferrucci L, Newman AB, Dullaart RP, Sgarbi JA, Ceresini G, 
Maciel RM, Westendorp RG, Jukema JW, Imaizumi M, Franklyn JA, Bauer DC, Walsh JP, Razvi S, Khaw KT, Cappola AR, Volzke H, Franco OH, Gussekloo J, Rodondi N, Peeters RP; Thyroid Studies Collaboration 2015 Subclinical hypothyroidism and the risk of stroke events and fatal stroke: an individual participant data analysis. J Clin Endocrinol Metab 100:2181-2191.

21. Collet TH, Bauer DC, Cappola AR, Asvold BO, Weiler S, Vittinghoff E, Gussekloo J, Bremner A, den Elzen WP, Maciel RM, Vanderpump MP, Cornuz J, Dorr M, Wallaschofski H, Newman AB, Sgarbi JA, Razvi S, Volzke H, Walsh JP, Aujesky D, Rodondi N; Thyroid Studies Collaboration 2014 Thyroid antibody status, subclinical hypothyroidism, and the risk of coronary heart disease: an individual participant data analysis. J Clin Endocrinol Metab 99:3353-3362.

22. Collet TH, Gussekloo J, Bauer DC, den Elzen WP, Cappola AR, Balmer P, Iervasi G, Asvold BO, Sgarbi JA, Volzke H, Gencer B, Maciel RM, Molinaro S, Bremner A, Luben RN, Maisonneuve P, Cornuz J, Newman AB, Khaw KT, Westendorp RG, Franklyn JA, Vittinghoff E, Walsh JP, Rodondi N; Thyroid Studies Collaboration 2012 Subclinical hyperthyroidism and the risk of coronary heart disease and mortality. Arch Intern Med 172:799809.

23. Gencer B, Collet TH, Virgini V, Bauer DC, Gussekloo J, Cappola AR, Nanchen D, den Elzen WP, Balmer P, Luben RN, Iacoviello M, Triggiani V, Cornuz J, Newman AB, Khaw KT, Jukema JW, Westendorp RG, Vittinghoff E, Aujesky D, Rodondi N; Thyroid Studies Collaboration 2012 Subclinical thyroid dysfunction and the risk of heart failure events: an individual participant data analysis from 6 prospective cohorts. Circulation 126:1040-1049.

24. Kus A, Szymanski K, Peeters RP, Miskiewicz P, Porcu E, Pistis G, Sanna S, Naitza S, Ploski R, Medici M, Bednarczuk T 2015 The association of thyroid peroxidase antibody risk loci with susceptibility to and phenotype of Graves' disease. Clin Endocrinol (Oxf) 83:556-562.

25. Porcu E, Medici M, Pistis G, Volpato CB, Wilson SG, Cappola AR, Bos SD, Deelen J, den Heijer M, Freathy RM, Lahti J, Liu C, Lopez LM, Nolte IM, O'Connell JR, Tanaka T, Trompet S, Arnold A, Bandinelli S, Beekman M, Bohringer S, Brown SJ, Buckley BM, Camaschella C, de Craen AJ, Davies G, de Visser MC, Ford I, Forsen T, Frayling TM, Fugazzola L, Gogele M, Hattersley AT, Hermus AR, Hofman A, Houwing-Duistermaat JJ, Jensen RA, Kajantie E, Kloppenburg M, Lim EM, Masciullo C, Mariotti S, Minelli C, Mitchell BD, Nagaraja R, NeteaMaier RT, Palotie A, Persani L, Piras MG, Psaty BM, Raikkonen K, Richards JB, Rivadeneira F, Sala C, Sabra MM, Sattar N, Shields BM, Soranzo N, Starr JM, Stott DJ, Sweep FC, Usala G, van der Klauw MM, van Heemst D, van Mullem A, Vermeulen SH, Visser WE, Walsh JP, Westendorp RG, Widen E, Zhai G, Cucca F, Deary IJ, Eriksson JG, Ferrucci L, Fox CS, Jukema JW, Kiemeney LA, Pramstaller PP, Schlessinger D, Shuldiner AR, Slagboom EP, Uitterlinden AG, Vaidya B, Visser TJ, Wolffenbuttel BH, Meulenbelt I, Rotter JI, Spector TD, Hicks AA, Toniolo D, Sanna S, Peeters RP, Naitza S 2013 A meta-analysis of thyroid-related traits reveals novel loci and gender-specific differences in the regulation of thyroid function. PLoS Genet 9:e1003266.

26. Schultheiss UT, Teumer A, Medici M, Li Y, Daya N, Chaker L, Homuth G, Uitterlinden AG, Nauck M, Hofman
A, Selvin E, Volzke H, Peeters RP, Kottgen A 2015 A genetic risk score for thyroid peroxidase antibodies associates with clinical thyroid disease in community-based populations. J Clin Endocrinol Metab 100:E799-807.

27. Andersen S, Pedersen KM, Bruun NH, Laurberg P 2002 Narrow individual variations in serum $\mathrm{T}(4)$ and $\mathrm{T}(3)$ in normal subjects: a clue to the understanding of subclinical thyroid disease. J Clin Endocrinol Metab 87:1068-1072.

28. Bommer M, Eversmann T, Pickardt R, Leonhardt A, Naber D 1990 Psychopathological and neuropsychological symptoms in patients with subclinical and remitted hyperthyroidism. Klin Wochenschr 68:552-558.

29. Fahrenfort JJ, Wilterdink AM, van der Veen EA 2000 Longterm residual complaints and psychosocial sequelae after remission of hyperthyroidism. Psychoneuroendocrinology 25:201-211.

30. Saravanan P, Chau WF, Roberts N, Vedhara K, Greenwood R, Dayan CM 2002 Psychological well-being in patients on "adequate" doses of L-thyroxine: results of a large, controlled community-based questionnaire study. Clin Endocrinol (Oxf) 57:577-585.

31. Stern RA, Robinson B, Thorner AR, Arruda JE, Prohaska ML, Prange AJ Jr 1996 A survey study of neuropsychiatric complaints in patients with Graves' disease. J Neuropsychiatry Clin Neurosci 8:181-185.

32. Wekking EM, Appelhof BC, Fliers E, Schene AH, Huyser J, Tijssen JG, Wiersinga WM 2005 Cognitive functioning and well-being in euthyroid patients on thyroxine replacement therapy for primary hypothyroidism. Eur $\mathrm{J}$ Endocrinol 153:747-753.

33. Hansen PS, Brix TH, Sorensen TI, Kyvik KO, Hegedus L 2004 Major genetic influence on the regulation of the pituitary-thyroid axis: a study of healthy Danish twins. J Clin Endocrinol Metab 89:1181-1187.

34. Medici M, Visser WE, Visser TJ, Peeters RP 2015 Genetic determination of the hypothalamic-pituitary-thyroid axis: where do we stand? Endocr Rev 36:214-244.

35. Medici M, Visser TJ, Peeters RP 2017 Genetics of thyroid function. Best Pract Res Clin Endocrinol Metab 31:129142.

36. Holmes MV, Ala-Korpela M, Smith GD 2017 Mendelian randomization in cardiometabolic disease: challenges in evaluating causality. Nat Rev Cardiol 14:577-590.

37. Zhao JV, Schooling CM 2017 Thyroid function and ischemic heart disease: a Mendelian randomization study. Sci Rep 7:8515.

38. Dumitrescu AM, Refetoff S 2000 Impaired sensitivity to thyroid hormone: defects of transport, metabolism and action. In: De Groot LJ, Chrousos G, Dungan K, Feingold KR, Grossman A, Hershman JM, Koch C, Korbonits M, McLachlan R, New M, Purnell J, Rebar R, Singer F, Vinik A (eds) Endotext [Internet]. MDText.com, Inc., South Dartmouth, MA.

39. van Gucht ALM, Moran C, Meima ME, Visser WE, Chatterjee K, Visser TJ, Peeters RP 2017 Resistance to thyroid hormone due to heterozygous mutations in thyroid hormone receptor alpha. Curr Top Dev Biol 125:337-355.

40. Hall MA, Moore JH, Ritchie MD 2016 Embracing complex associations in common traits: critical considerations for precision medicine. Trends Genet 32:470-484.

41. Inouye M, Ripatti S, Kettunen J, Lyytikainen LP, Oksala N, Laurila PP, Kangas AJ, Soininen P, Savolainen MJ, Viikari J, Kahonen M, Perola M, Salomaa V, Raitakari O, Lehtimaki T, Taskinen MR, Jarvelin MR, Ala-Korpela M, 
Palotie A, de Bakker PI 2012 Novel Loci for metabolic networks and multi-tissue expression studies reveal genes for atherosclerosis. PLoS Genet 8:e1002907.

42. Knebel B, Strassburger K, Szendroedi J, Kotzka J, Scheer M, Nowotny B, Mussig K, Lehr S, Pacini G, Finner H, Kluppelholz B, Giani G, Al-Hasani H, Roden M; German Diabetes Study Group 2016 Specific metabolic profiles and their relationship to insulin resistance in recent-onset type 1 and type 2 diabetes. J Clin Endocrinol Metab 101: 2130-2140.

43. Makinen VP, Civelek M, Meng Q, Zhang B, Zhu J, Levian C, Huan T, Segre AV, Ghosh S, Vivar J, Nikpay M, Stewart AF, Nelson CP, Willenborg C, Erdmann J, Blakenberg S, O’Donnell CJ, Marz W, Laaksonen R, Epstein SE, Kathiresan S, Shah SH, Hazen SL, Reilly MP; Coronary ARtery DIsease Genome-Wide Replication And Meta-Analysis (CARDIoGRAM) Consortium, Lusis AJ, Samani NJ, Schunkert H, Quertermous T, McPherson R, Yang X, Assimes TL 2014 Integrative genomics reveals novel molecular pathways and gene networks for coronary artery disease. PLoS Genet 10:e1004502.

44. Tribulova N, Knezl V, Shainberg A, Seki S, Soukup T 2010 Thyroid hormones and cardiac arrhythmias. Vascul Pharmacol 52:102-112.

45. Le Bouter S, Demolombe S, Chambellan A, Bellocq C, Aimond F, Toumaniantz G, Lande G, Siavoshian S, Baro I, Pond AL, Nerbonne JM, Leger JJ, Escande D, Charpentier F 2003 Microarray analysis reveals complex remodeling of cardiac ion channel expression with altered thyroid status: relation to cellular and integrated electrophysiology. Circ Res 92:234-242.

46. Pachucki J, Burmeister LA, Larsen PR 1999 Thyroid hormone regulates hyperpolarization-activated cyclic nucleotidegated channel (HCN2) mRNA in the rat heart. Circ Res 85: 498-503.

47. Bacova BS, Vinczenzova C, Zurmanova J, Kasparova D, Knezl V, Benova TE, Pavelka S, Soukup T, Tribulova N 2017 Altered thyroid status affects myocardial expression of connexin-43 and susceptibility of rat heart to malignant arrhythmias that can be partially normalized by red palm oil intake. Histochem Cell Biol 147:63-73.

48. Nadkarni PJ, Sharma M, Zinsmeister B, Wartofsky L, Burman KD 2008 Thyrotoxicosis-induced ventricular arrhythmias. Thyroid 18:1111-1114.

49. Lein ES, Hawrylycz MJ, Ao N, Ayres M, Bensinger A, Bernard A, Boe AF, Boguski MS, Brockway KS, Byrnes EJ, Chen L, Chen L, Chen TM, Chin MC, Chong J, Crook BE, Czaplinska A, Dang CN, Datta S, Dee NR, Desaki AL, Desta T, Diep E, Dolbeare TA, Donelan MJ, Dong HW, Dougherty JG, Duncan BJ, Ebbert AJ, Eichele G, Estin LK, Faber C, Facer BA, Fields R, Fischer SR, Fliss TP, Frensley C, Gates SN, Glattfelder KJ, Halverson KR, Hart MR, Hohmann JG, Howell MP, Jeung DP, Johnson RA, Karr PT, Kawal R, Kidney JM, Knapik RH, Kuan CL, Lake JH, Laramee AR, Larsen KD, Lau C, Lemon TA, Liang AJ, Liu Y, Luong LT, Michaels J, Morgan JJ, Morgan RJ, Mortrud MT, Mosqueda NF, Ng LL, Ng R, Orta GJ, Overly CC, Pak TH, Parry SE, Pathak SD, Pearson OC, Puchalski RB, Riley ZL, Rockett HR, Rowland SA, Royall JJ, Ruiz MJ, Sarno NR, Schaffnit K, Shapovalova NV, Sivisay T, Slaughterbeck CR, Smith SC, Smith KA, Smith BI, Sodt AJ, Stewart NN, Stumpf KR, Sunkin SM, Sutram M, Tam A, Teemer CD, Thaller C, Thompson CL, Varnam LR, Visel A, Whitlock RM,
Wohnoutka PE, Wolkey CK, Wong VY, Wood M, Yaylaoglu MB, Young RC, Youngstrom BL, Yuan XF, Zhang B, Zwingman TA, Jones AR 2007 Genome-wide atlas of gene expression in the adult mouse brain. Nature 445: $168-176$.

50. Wikstrom L, Johansson C, Salto C, Barlow C, Campos Barros A, Baas F, Forrest D, Thoren P, Vennstrom B 1998 Abnormal heart rate and body temperature in mice lacking thyroid hormone receptor alpha 1. EMBO J 17:455-461.

51. Hones GS, Rakov H, Logan J, Liao XH, Werbenko E, Pollard AS, Praestholm SM, Siersbaek MS, Rijntjes E, Gassen J, Latteyer S, Engels K, Strucksberg KH, Kleinbongard P, Zwanziger D, Rozman J, Gailus-Durner V, Fuchs H, Hrabe de Angelis M, Klein-Hitpass L, Kohrle J, Armstrong DL, Grontved L, Bassett JHD, Williams GR, Refetoff S, Fuhrer D, Moeller LC 2017 Noncanonical thyroid hormone signaling mediates cardiometabolic effects in vivo. Proc Natl Acad Sci U S A 114:E11323-E11332.

52. Flamant F, Cheng SY, Hollenberg AN, Moeller LC, Samarut J, Wondisford FE, Yen PM, Refetoff S 2017 Thyroid hormone signaling pathways: time for a more precise nomenclature. Endocrinology 158:2052-2057.

53. Sawin CT, Geller A, Wolf PA, Belanger AJ, Baker E, Bacharach P, Wilson PW, Benjamin EJ, D'Agostino RB 1994 Low serum thyrotropin concentrations as a risk factor for atrial fibrillation in older persons. N Engl J Med 331:1249-1252.

54. Cappola AR, Fried LP, Arnold AM, Danese MD, Kuller LH, Burke GL, Tracy RP, Ladenson PW 2006 Thyroid status, cardiovascular risk, and mortality in older adults. JAMA 295: 1033-1041.

55. Heeringa J, Hoogendoorn EH, van der Deure WM, Hofman A, Peeters RP, Hop WC, den Heijer M, Visser TJ, Witteman JC 2008 High-normal thyroid function and risk of atrial fibrillation: the Rotterdam study. Arch Intern Med 168:2219-2224.

56. Cappola AR, Arnold AM, Wulczyn K, Carlson M, Robbins J, Psaty BM 2015 Thyroid function in the euthyroid range and adverse outcomes in older adults. J Clin Endocrinol Metab 100:1088-1096.

57. Jonklaas J, Davidson B, Bhagat S, Soldin SJ 2008 Triiodothyronine levels in athyreotic individuals during levothyroxine therapy. JAMA 299:769-777.

58. Gullo D, Latina A, Frasca F, Le Moli R, Pellegriti G, Vigneri R 2011 Levothyroxine monotherapy cannot guarantee euthyroidism in all athyreotic patients. PLoS One 6: e22552.

59. Flynn RW, Bonellie SR, Jung RT, MacDonald TM, Morris AD, Leese GP 2010 Serum thyroid-stimulating hormone concentration and morbidity from cardiovascular disease and fractures in patients on long-term thyroxine therapy. J Clin Endocrinol Metab 95:186-193.

60. Lee YS, Choi JW, Bae EJ, Park WI, Lee HJ, Oh PS 2015 The corrected QT (QTc) prolongation in hyperthyroidism and the association of thyroid hormone with the QTc interval. Korean J Pediatr 58:263-266.

61. Dorr M, Ruppert J, Robinson DM, Kors JA, Felix SB, Volzke H 2006 The relation of thyroid function and ventricular repolarization: decreased serum thyrotropin levels are associated with short rate-adjusted QT intervals. J Clin Endocrinol Metab 91:4938-4942.

62. Schenck JB, Rizvi AA, Lin T 2006 Severe primary hypothyroidism manifesting with torsades de pointes. Am J Med Sci 331:154-156. 
63. Silva JE, Bianco SD 2008 Thyroid-adrenergic interactions: physiological and clinical implications. Thyroid 18: 157-165.

64. Figge HL, Figge J 1990 The effects of amiodarone on thyroid hormone function: a review of the physiology and clinical manifestations. J Clin Pharmacol 30:588-595.

65. Basaria S, Cooper DS 2005 Amiodarone and the thyroid. Am J Med 118:706-714.

66. Le Bouter S, El Harchi A, Marionneau C, Bellocq C, Chambellan A, van Veen T, Boixel C, Gavillet B, Abriel H, Le Quang K, Chevalier JC, Lande G, Leger JJ, Charpentier F, Escande D, Demolombe S 2004 Long-term amiodarone administration remodels expression of ion channel transcripts in the mouse heart. Circulation 110: 3028-3035.

67. Kim EE, Shekhar A, Lu J, Lin X, Liu FY, Zhang J, Delmar M, Fishman GI 2014 PCP4 regulates Purkinje cell excitability and cardiac rhythmicity. J Clin Invest 124: 5027-5036.

68. Faber J, Wiinberg N, Schifter S, Mehlsen J 2001 Haemodynamic changes following treatment of subclinical and overt hyperthyroidism. Eur J Endocrinol 145:391396.

69. Sgarbi JA, Villaca FG, Garbeline B, Villar HE, Romaldini JH 2003 The effects of early antithyroid therapy for endogenous subclinical hyperthyroidism in clinical and heart abnormalities. J Clin Endocrinol Metab 88:16721677.

70. Kaminski G, Michalkiewicz D, Makowski K, Podgajny Z, Szalus N, Ruchala M, Szczepanek E, Gielerak G 2011 Prospective echocardiographic evaluation of patients with endogenous subclinical hyperthyroidism and after restoring euthyroidism. Clin Endocrinol (Oxf) 74:501-507.

71. Somwaru LL, Arnold AM, Cappola AR 2011 Predictors of thyroid hormone initiation in older adults: results from the cardiovascular health study. J Gerontol A Biol Sci Med Sci 66:809-814.

72. Bakker O, Hudig F, Meijssen S, Wiersinga WM 1998 Effects of triiodothyronine and amiodarone on the promoter of the human LDL receptor gene. Biochem Biophys Res Commun 249:517-521.

73. Walton KW, Campbell DA, Tonks EL 1965 The significance of alterations in serum lipids in thyroid dysfunction. I. The relation between serum lipoproteins, carotenoids and vitamin A in hypothyroidism and thyrotoxicosis. Clin Sci 29:199-215.

74. Angelin B, Einarsson K, Leijd B 1983 Bile acid metabolism in hypothyroid subjects: response to substitution therapy. Eur J Clin Invest 13:99-106.

75. Astapova I, Ramadoss P, Costa-e-Sousa RH, Ye F, Holtz KA, Li Y, Niepel MW, Cohen DE, Hollenberg AN 2014 Hepatic nuclear corepressor 1 regulates cholesterol absorption through a TRbeta1-governed pathway. J Clin Invest 124:1976-1986.

76. O'Brien T, Dinneen SF, O’Brien PC, Palumbo PJ 1993 Hyperlipidemia in patients with primary and secondary hypothyroidism. Mayo Clin Proc 68:860-866.

77. Sinha RA, Singh BK, Yen PM 2018 Direct effects of thyroid hormones on hepatic lipid metabolism. Nat Rev Endocrinol 14:259-269.

78. Tan KC, Shiu SW, Kung AW 1998 Effect of thyroid dysfunction on high-density lipoprotein subfraction metabolism: roles of hepatic lipase and cholesteryl ester transfer protein. J Clin Endocrinol Metab 83:2921-2924.
79. Johansson L, Rudling M, Scanlan TS, Lundasen T, Webb P, Baxter J, Angelin B, Parini P 2005 Selective thyroid receptor modulation by $\mathrm{GC}-1$ reduces serum lipids and stimulates steps of reverse cholesterol transport in euthyroid mice. Proc Natl Acad Sci U S A 102:10297-10302.

80. Pearce EN 2012 Update in lipid alterations in subclinical hypothyroidism. J Clin Endocrinol Metab 97:326-333.

81. Kuusi T, Taskinen MR, Nikkila EA 1988 Lipoproteins, lipolytic enzymes, and hormonal status in hypothyroid women at different levels of substitution. J Clin Endocrinol Metab 66:51-56.

82. Kung AW, Pang RW, Lauder I, Lam KS, Janus ED 1995 Changes in serum lipoprotein(a) and lipids during treatment of hyperthyroidism. Clin Chem 41:226-231.

83. Ladenson PW, Kristensen JD, Ridgway EC, Olsson AG, Carlsson B, Klein I, Baxter JD, Angelin B 2010 Use of the thyroid hormone analogue eprotirome in statin-treated dyslipidemia. N Engl J Med 362:906-916.

84. Angelin B, Kristensen JD, Eriksson M, Carlsson B, Klein I, Olsson AG, Chester Ridgway E, Ladenson PW 2015 Reductions in serum levels of LDL cholesterol, apolipoprotein B, triglycerides and lipoprotein(a) in hypercholesterolaemic patients treated with the liver-selective thyroid hormone receptor agonist eprotirome. J Intern Med 277: 331-342.

85. Rugge JB, Bougatsos C, Chou R 2015 Screening and treatment of thyroid dysfunction: an evidence review for the U.S. Preventive Services Task Force. Ann Intern Med 162:35-45.

86. Saric MS, Jurasic MJ, Sovic S, Kranjcec B, Glivetic T, Demarin V 2017 Dyslipidemia in subclinical hypothyroidism requires assessment of small dense low density lipoprotein cholesterol (sdLDL-C). Rom J Intern Med 55: 159-166.

87. Harada PHN, Buring JE, Cook NR, Cobble ME, Kulkarni KR, Mora S 2017 Impact of subclinical hypothyroidism on cardiometabolic biomarkers in women. J Endocr Soc 1: 113-123.

88. Ittermann T, Tiller D, Meisinger C, Agger C, Nauck M, Rettig R, Hofman A, Jorgensen T, Linneberg A, Witteman JC, Franco OH, Greiser KH, Werdan K, Doring A, Kluttig A, Stricker BH, Volzke H 2013 High serum thyrotropin levels are associated with current but not with incident hypertension. Thyroid 23:955-963.

89. Zhou Y, Chen Y, Cao X, Liu C, Xie Y 2014 Association between plasma homocysteine status and hypothyroidism: a meta-analysis. Int J Clin Exp Med 7:4544-4553.

90. Clausen P, Mersebach H, Nielsen B, Feldt-Rasmussen B, Feldt-Rasmussen U 2009 Hypothyroidism is associated with signs of endothelial dysfunction despite 1-year replacement therapy with levothyroxine. Clin Endocrinol (Oxf) 70:932-937.

91. Razvi S, Weaver JU, Butler TJ, Pearce SH 2012 Levothyroxine treatment of subclinical hypothyroidism, fatal and nonfatal cardiovascular events, and mortality. Arch Intern Med 172:811-817.

92. Asvold BO, Vatten LJ, Bjoro T, Bauer DC, Bremner A, Cappola AR, Ceresini G, den Elzen WP, Ferrucci L, Franco OH, Franklyn JA, Gussekloo J, Iervasi G, Imaizumi M, Kearney PM, Khaw KT, Maciel RM, Newman AB, Peeters RP, Psaty BM, Razvi S, Sgarbi JA, Stott DJ, Trompet S, Vanderpump MP, Volzke H, Walsh JP, Westendorp RG, Rodondi N; Thyroid Studies Collaboration 2015 Thyroid function within the normal range and 
risk of coronary heart disease: an individual participant data analysis of 14 cohorts. JAMA Intern Med 175:10371047.

93. Bano A, Chaker L, Mattace-Raso FUS, van der Lugt A, Ikram MA, Franco OH, Peeters RP, Kavousi M 2017 Thyroid function and the risk of atherosclerotic cardiovascular morbidity and mortality: the Rotterdam Study. Circ Res 121:1392-1400.

94. Stott DJ, Rodondi N, Kearney PM, Ford I, Westendorp RGJ, Mooijaart SP, Sattar N, Aubert CE, Aujesky D, Bauer DC, Baumgartner C, Blum MR, Browne JP, Byrne S, Collet TH, Dekkers OM, den Elzen WPJ, Du Puy RS, Ellis G, Feller M, Floriani C, Hendry K, Hurley C, Jukema JW, Kean S, Kelly M, Krebs D, Langhorne P, McCarthy G, McCarthy V, McConnachie A, McDade M, Messow M, O'Flynn A, O'Riordan D, Poortvliet RKE, Quinn TJ, Russell A, Sinnott C, Smit JWA, Van Dorland HA, Walsh KA, Walsh EK, Watt T, Wilson R, Gussekloo J, Group TS 2017 Thyroid hormone therapy for older adults with subclinical hypothyroidism. N Engl J Med 376:25342544.

95. Danzi S, Klein I 2014 Thyroid disease and the cardiovascular system. Endocrinol Metab Clin North Am 43: $517-528$.

96. Holt E, Sjaastad I, Lunde PK, Christensen G, Sejersted OM 1999 Thyroid hormone control of contraction and the $\mathrm{Ca}(2+)$-ATPase/phospholamban complex in adult rat ventricular myocytes. J Mol Cell Cardiol 31:645-656.

97. Kiss E, Jakab G, Kranias EG, Edes I 1994 Thyroid hormone-induced alterations in phospholamban protein expression. Regulatory effects on sarcoplasmic reticulum $\mathrm{Ca} 2+$ transport and myocardial relaxation. Circ Res 75: 245-251.

98. Kranias EG, Hajjar RJ 2012 Modulation of cardiac contractility by the phospholamban/SERCA2a regulatome. Circ Res 110:1646-1660.

99. Hoit BD, Khoury SF, Shao Y, Gabel M, Liggett SB, Walsh RA 1997 Effects of thyroid hormone on cardiac beta-adrenergic responsiveness in conscious baboons. Circulation 96:592-598.

100. Bachman ES, Hampton TG, Dhillon H, Amende I, Wang J, Morgan JP, Hollenberg AN 2004 The metabolic and cardiovascular effects of hyperthyroidism are largely independent of beta-adrenergic stimulation. Endocrinology 145:2767-2774.

101. Ojamaa K, Klemperer JD, Klein I 1996 Acute effects of thyroid hormone on vascular smooth muscle. Thyroid 6: 505-512.

102. Silva JE 1995 Thyroid hormone control of thermogenesis and energy balance. Thyroid 5:481-492.

103. Imai T, Hirata Y, Iwashina M, Marumo F 1995 Hormonal regulation of rat adrenomedullin gene in vasculature. Endocrinology 136:1544-1548.

104. Lewicki JA, Protter PA 1994 Physiological studies of the natriuretic family. In: Laragh JH, Brenner BB (eds) Hypertension: Pathophysiology, Diagnosis, and Management. Raven Press, New York, NY, pp 1029-1053.

105. Goldman S, Olajos M, Morkin E 1984 Control of cardiac output in thyrotoxic calves. Evaluation of changes in the systemic circulation. J Clin Invest 73:358-365.

106. Feldman T, Borow KM, Sarne DH, Neumann A, Lang RM 1986 Myocardial mechanics in hyperthyroidism: importance of left ventricular loading conditions, heart rate and contractile state. J Am Coll Cardiol 7:967-974.
107. Biondi B, Palmieri EA, Lombardi G, Fazio S 2002 Effects of thyroid hormone on cardiac function: the relative importance of heart rate, loading conditions, and myocardial contractility in the regulation of cardiac performance in human hyperthyroidism. J Clin Endocrinol Metab 87:968974.

108. Biondi B 2012 Mechanisms in endocrinology: heart failure and thyroid dysfunction. Eur J Endocrinol 167:609618.

109. Biondi B, Palmieri EA, Fazio S, Cosco C, Nocera M, Sacca L, Filetti S, Lombardi G, Perticone F 2000 Endogenous subclinical hyperthyroidism affects quality of life and cardiac morphology and function in young and middle-aged patients. J Clin Endocrinol Metab 85:47014705.

110. Davis FB, Mousa SA, O'Connor L, Mohamed S, Lin HY, Cao HJ, Davis PJ 2004 Proangiogenic action of thyroid hormone is fibroblast growth factor-dependent and is initiated at the cell surface. Circ Res 94:1500-1506.

111. Al Husseini A, Bagnato G, Farkas L, Gomez-Arroyo J, Farkas D, Mizuno S, Kraskauskas D, Abbate A, Van Tassel B, Voelkel NF, Bogaard HJ 2013 Thyroid hormone is highly permissive in angioproliferative pulmonary hypertension in rats. Eur Respir J 41:104-114.

112. Marvisi M, Zambrelli P, Brianti M, Civardi G, Lampugnani R, Delsignore R 2006 Pulmonary hypertension is frequent in hyperthyroidism and normalizes after therapy. Eur J Intern Med 17:267-271.

113. Pingitore A, Iervasi G, Barison A, Prontera C, Pratali L, Emdin M, Giannessi D, Neglia D 2006 Early activation of an altered thyroid hormone profile in asymptomatic or mildly symptomatic idiopathic left ventricular dysfunction. J Card Fail 12:520-526.

114. Kannan L, Shaw PA, Morley MP, Brandimarto J, Fang JC, Sweitzer NK, Cappola TP, Cappola AR 2018 Thyroid dysfunction in heart failure and cardiovascular outcomes. Circ Heart Fail 11:e005266.

115. Iervasi G, Pingitore A, Landi P, Raciti M, Ripoli A, Scarlattini M, L'Abbate A, Donato L 2003 Low-T3 syndrome: a strong prognostic predictor of death in patients with heart disease. Circulation 107:708-713.

116. Simonides WS, Mulcahey MA, Redout EM, Muller A, Zuidwijk MJ, Visser TJ, Wassen FW, Crescenzi A, daSilva WS, Harney J, Engel FB, Obregon MJ, Larsen PR, Bianco AC, Huang SA 2008 Hypoxia-inducible factor induces local thyroid hormone inactivation during hypoxicischemic disease in rats. J Clin Invest 118:975-983.

117. Pingitore A, Galli E, Barison A, Iervasi A, Scarlattini M, Nucci D, L'Abbate A, Mariotti R, Iervasi G 2008 Acute effects of triiodothyronine (T3) replacement therapy in patients with chronic heart failure and low-T3 syndrome: a randomized, placebo-controlled study. J Clin Endocrinol Metab 93:1351-1358.

118. Holmager P, Schmidt U, Mark P, Andersen U, Dominguez H, Raymond I, Zerahn B, Nygaard B, Kistorp C, Faber J 2015 Long-term L-Triiodothyronine (T3) treatment in stable systolic heart failure patients: a randomised, doubleblind, cross-over, placebo-controlled intervention study. Clin Endocrinol (Oxf) 83:931-937.

119. Novitzky D, Cooper DK, Human PA, Reichart B, Zuhdi N 1988 Triiodothyronine therapy for heart donor and recipient. J Heart Transplant 7:370-376.

120. Klemperer JD, Klein I, Gomez M, Helm RE, Ojamaa K, Thomas SJ, Isom OW, Krieger K 1995 Thyroid hormone 
treatment after coronary-artery bypass surgery. $\mathrm{N}$ Engl $\mathrm{J}$ Med 333:1522-1527.

121. Goldman S, McCarren M, Morkin E, Ladenson PW, Edson R, Warren S, Ohm J, Thai H, Churby L, Barnhill J, O'Brien T, Anand I, Warner A, Hattler B, Dunlap M, Erikson J, Shih MC, Lavori P 2009 DITPA (3,5-diiodothyropropionic acid), a thyroid hormone analog to treat heart failure: Phase II trial veterans affairs cooperative study. Circulation 119:30933100.

122. Rhee CM, Curhan GC, Alexander EK, Bhan I, Brunelli SM 2013 Subclinical hypothyroidism and survival: the effects of heart failure and race. J Clin Endocrinol Metab 98:2326-2336.

123. d'Amati G, di Gioia CR, Mentuccia D, Pistilli D, ProiettiPannunzi L, Miraldi F, Gallo P, Celi FS 2001 Increased expression of thyroid hormone receptor isoforms in endstage human congestive heart failure. J Clin Endocrinol Metab 86:2080-2084.

124. Belke DD, Gloss B, Swanson EA, Dillmann WH 2007 Adeno-associated virus-mediated expression of thyroid hormone receptor isoforms-alpha1 and -beta1 improves contractile function in pressure overload-induced cardiac hypertrophy. Endocrinology 148:2870-2877.

125. Modesti PA, Marchetta M, Gamberi T, Lucchese G, Maccherini M, Chiavarelli M, Modesti A 2008 Reduced expression of thyroid hormone receptors and beta-adrenergic receptors in human failing cardiomyocytes. Biochem Pharmacol 75:900-906.

Address correspondence to: Anne R. Cappola, MD, MSc Division of Endocrinology, Diabetes, and Metabolism Perelman School of Medicine at the University of Pennsylvania 3400 Civic Center Boulevard Philadelphia, PA 19104

E-mail: acappola@mail.med.upenn.edu

\section{Appendix}

Working Group Members:

Writing Group:

Anne R. Cappola, MD, ScM, Perelman School of Medicine at the University of Pennsylvania; Akshay S. Desai, MD, MPH, Brigham and Women's Hospital; Marco Medici, $\mathrm{MD}, \mathrm{PhD}, \mathrm{MSc}$, Erasmus University Medical Center; Lawton Cooper, MD, MPH, National Heart, Lung, and Blood Institute, Debra Egan, MPH, National Center for Complementary and Integrative Health; George Sopko, MD, MPH, National Heart, Lung, and Blood Institute; Glenn I. Fishman, MD, NYU School of Medicine; Steven Goldman, MD, University of Arizona; David S. Cooper, MD, Johns Hopkins University School of Medicine; Samia Mora, MD, MHS; Brigham and Women's Hospital; Peter J. Kudenchuk, MD, University of Washington; Anthony N. Hollenberg, MD, Weill Cornell Medicine; Cheryl L. McDonald, MD, National Heart, Lung, and Blood Institute;
Paul W. Ladenson, MD, Johns Hopkins University School of Medicine

Members:

Francesco S. Celi, MD, MHSc, Virginia Commonwealth University; Wolfgang Dillman, MD, University of California San Diego; Christina Ellervik, MD, PhD, DMSci, Boston Children's Hospital; A. Martin Gerdes, PhD, New York Institute of Technology College of Osteopathic Medicine; Carolyn Ho, MD, Brigham and Women's Hospital; Giorgio Iervasi, MD, Italian National Research Council; Amir Lerman, MD, Mayo Clinic; Ayako Makino, PhD, University of Arizona; Kaie Ojamaa, PhD, New York Institute of Technology College of Osteopathic Medicine; Robin Peeters, $\mathrm{MD}, \mathrm{PhD}$, Erasmus University Medical Center; Alessandro Pingitore, MD, PhD, Italian National Research Council; Salman Razvi, MD, Newcastle University; Ari J. Wassner, MD, Boston Children's Hospital 